\title{
Review
}

\section{THE LEYDIG CELLS OF THE TESTIS ORIGINATE FROM THE MICROVASCULAR PERICYTES}

\author{
Michail S. Davidoff \\ University Medical Center Hamburg-Eppendorf, Hamburg, Germany
}

\section{ABSTRACT}

This review offers some clarifying thoughts about the nature and origin of the fetal and adult Leydig cells, supporting the conception that the pericytes (the periendothelial cells) and the smooth muscle cells of the microvasculature, that represent the main omnipresent adult stem cell population of the mammalian organism, are the Leydig cell ancestors. Our attention is specifically dedicated to the numerous contradictions as well as ambiguities concerning the hypotheses that the mesenchymal stromal cells (MSCs), the neural crest stem cells (NCSCs) and the peritubular myoid stem cells (PMCs) represent the stem ancestors of the Leydig cells. In effect, it becomes evident that the only pluripotent stem cell-like cells in the vertebrate body, including the testis, are the pericytes. The pericytes are derivate of the embryonal epiblast and retain its pluripotency within the microvascular niches where they are disseminated during the embryo- and fetogenesis and are stored as a resting adult stem cell population for tissue generation, maintenance, repair and regeneration. The pluripotency of the epiblast and the pericytes themselves are responsible and explain the neural features of the Leydig cells. Thus, both NCSCs and PMCs are not the ancestors of the pericytes, respectively of the Leydig cells. Biomed Rev 2017; 28: 1-21.

Keywords: Leydig cells, origin, microvascular pericytes, smooth muscle cells, Leydig stem cells

\section{INTRODUCTION}

During the last four decades a lot of new information about the testosterone producing Leydig cells of the mammalian testis has been published. It became evident that the Leydig cells are not pure endocrine cells because they express also characteristic marker substances of nerve and glial cells, which allowed their designation as neuroendocrine cells (1-9). This fact evoked again the question regarding the origin (the ancestors) of Leydig cells. It was unequivocally evidenced that Leydig cells originate from stem cells (10-13). Most authors represented the opinion that these cells are of mesodermal origin. Recently, it was revealed that Leydig stem cells are the pericytes and the smooth muscle cells of the testis microvasculature $(14,15)$. Beside the fact that these results were confirmed for nearly all organs of the body $(14,16,17)$, until now contradictory interpretations exist concerning these two important topics. Even in the newest very informative articles by the group of Ge (18-20) the hypothesis of peritubular myoid stem cell origin of Leydig cells was favored.

\section{ORIGIN OF THE LEYDIG CELLS}

The ancestors of the adult Leydig cells are the testicular microvascular pericytes and smooth muscle cells. The pericyte ancestors are produced by the pluripotent epiblast cells which originate from the blastocyst inner cell mass in the very early embryogenesis (21). The pericytes are disseminated throughout the whole organism with the developing blood vessels $(22,23)$ and become stored within microvascular niches (24) as a resting, reserve population for tissue generation, physiological tissue maintenance and repair as well as for regen-

Received 24 November 2017, accepted 7 December 2017.

Correspondence to: Prof. Dr. med. Michail Davidoff, Universitry Medical Center Hamburg- Eppendorf, Museum of Medical History, N30b, Martinistrasse 52, D-20246 Hamburg, Germany. Tel: +49 (0) 40 7410-54482; E-mail: davidoff@uke.de 


\section{Zygote}

$\downarrow$

\section{Morula}

$\downarrow$

\section{Blastocyst}

\section{Trophectoderm}

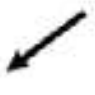

\section{$>$}

\section{Inner Cell Mass}

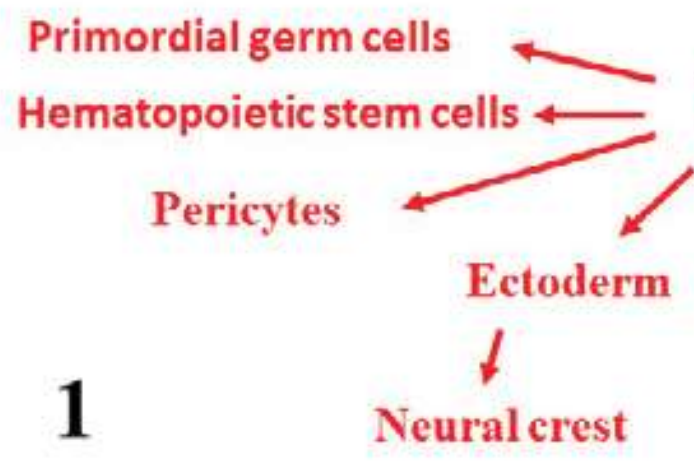

Figure 1. Depicts the very early stages of the zygote and the blastocyst differentiation. Note that the first cell populations derived from the epiblast are the primordial germ cells, the hematopoietic stem cells and the pericytes whereas the neural crest originates a bit later from the one of the primitive embryonic germ layers, the ectoderm (epiblast/ectoderm).

eration in the adult organism (5, 6, 25-30).

The epiblast is a derivative of the internal cell mass of the blastocyst. It arises during the postimplantation gastrulation in the very early embryogenesis (31-36). The epiblast produces firstly three cell phenotypes, namely, the pluripotent primordial germ cells (PGCs), the multipotent hematopoietic stem cells (HSCs) and the pluripotent pericytes $(15,37)$. Shortly after that, the epiblast generates the three primary germ layers: ectoderm, mesoderm and endoderm that are responsible for the building of all tissues and organs in a vertebrate organism (Fig. 1;43). It is well known that the ectoderm is the ancestor of the neural crest (see below).

Until now, different ancestors of the Leydig cells were supposed, such as: mesodermal (mesenchymal-like) stem cells $(4,5,9,25,44-52)$, peritubular myoid/fibroblast stem cells $(19,20,53-60)$, peritubular or perivascular fibroblastlike stem cells $(45,50,51,53-55,61,62,64-70)$, neural crest stem cells $(48,71-77)$, perivascular stem cells $(63,78,79)$, endothelial cells $(63,80)$, bone marrow cells $(81,82)$, the pericytes and the smooth muscle cells of the microvasculature $(14,15)$. Also multiple origins are presumed $(19,20,52$,
$58,83)$. In this respect connective tissue cells that include lymphatic endothelial cells, perivascular fibroblast-like cells and pericytes were mentioned $(54,61,84,85)$

Thus the problem of the origin of the Leydig cells remains still controversial. There are two main reasons for this fact. In the most studies the fast transdifferentiation $(14,15$, 86) of the stem cell progeny (the transit amplifying cells) into immature Leydig cells was not really documented. This caused a serious difficulty in the establishment and understanding of the Leydig cell genetic lineage. Further, a subpopulation of human perivascular cells that express both pericytes and mesenchymal stem cell (MSC) markers in situ was identified (22). If isolated in culture this population expand and show clonally multipotent features, providing evidence that MSCs found throughout fetal and adult tissues are members of the pericyte family of cells. Thus blood vessel walls harbor a reserve of stem/progenitor cells that may be integral to the origin of the elusive MSCs and other related adult stem cells $(78,87)$. Taking into account the spatially and temporally association of the microvasculature and the adult (Leydig) stem cells and that the cardiovascular system 


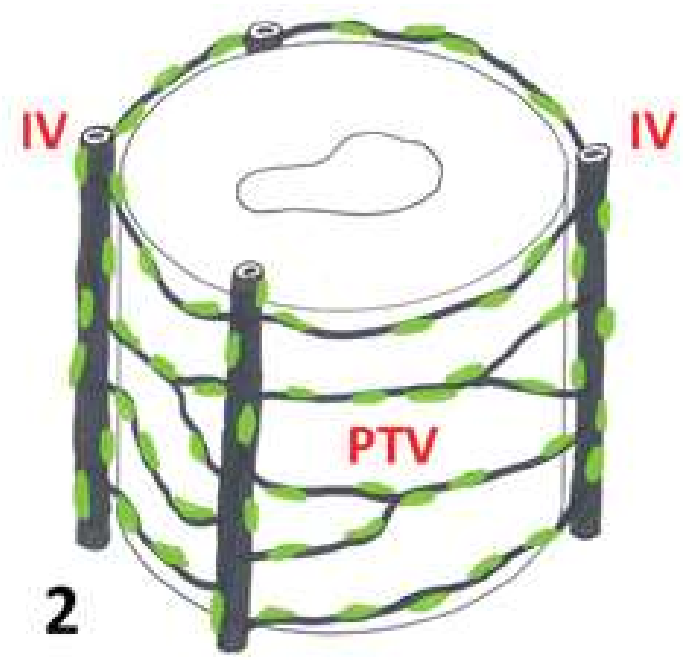

Figure 2. The diagram shows the relationship between the testicular blood vessels and the seminiferous tubule. IV - intertubular vessels; PTV-peritubular vessels. The green oval blood vessel components illustrate the pericytes. Note the close relationship between the blood vessels/pericytes and the tubule wall and that parts of the tubule surface are free of blood vessels.

becomes the first functioning system in the embryo (88-90), it is surprising that in the most studies no comparison between the course of the testicular vasculature (91-94) and the localization of the stem Leydig cells was done. This close relationship between Leydig cells and blood vessels is obligatory taking into consideration that the Leydig cells are neuroendocrine cells (95). Even the important close spatial, functional and organizational relationship between the testis vasculature and the seminiferous tubules from early embryogenesis to adult was not really respected $(60,96,97)$ (Fig. 2 ). The ignorance of this fact led to the impression for the peritubular location of the stem Leydig cells (see below). However, numerous authors draw attention that Leydig cells are located in the vicinity or in close contact with testicular blood vessels $(87,98-100)$ but this fact was not interpreted satisfactory and in details.

\section{ORIGIN OF THE PERICYTES}

The pericytes are a brilliant achievement of the biological nature aiming to supply every organ with an omnipresent population of pluripotent adult stem cells. The pericytes originate very early in the embryogenesis from the epiblast (primitive ectoderm). The pericytes are pluripotent stem cells (such as the epiblast; 23). They possess ectodermal, endodermal and mesodermal lineage progeny. The adult stem/progenitor pericytes (the epiblast representatives) of the adult vertebrate organism are located in authentic microvascular niches as reserve (resting, silencing) adult stem cell population for tissue/ organ generation, maintenance, repair and regeneration.

For a long time the origin of the pericytes was presented as multiple $(15,101)$. Meanwhile a lot of information accumulate that the pericytes originate from the pluripotent epiblast and represent pluripotent stem cells $(22,23,41,42)$. They retain the possibility to produce cells characteristic for all three embryonal germ-layers: ectoderm, mesoderm and endoderm. This is also the reason why the progeny of the pericytes is so meaningful and variable and why these cells in different stages of differentiation and variable environments may have mesenchymal, neural and epithelial characteristics. As Dore-Duffy (25) emphasized, once isolated, pericytes rapidly differentiate along multiple lineages depending on the regulatory signals present in the microenvironment. It is this pluripotentiality and the ability to migrate as well as the lack of pericyte specific markers that has led to the enormous confusion about this cell type. This also provides serious difficulties for the scientist to follow a logical lineage differentiation or pathway of the pluripotent pericytes. Moreover, in cell cultures these cells may behave different as in vivo which was also evidenced for the mesenchymal stem cells and the mesodermal progenitor cells $(17,102-104)$. In this respect Zwaka and Thomson (21) pointed out that it is remarkable that permanent pluripotent embryonic stem cell lines can be derived from preimplantation embryos at all, because, in vivo, pluripotent cells of the early mammalian embryo proliferate only briefly before becoming cells with a more restricted development potential. Moreover, the authors (25) underline that the embryo-derived stem cells are in some sense tissue culture artifacts (105-107) that do not exist in this form and functions in the living organisms. As discussed below, the representatives of the embryonal epiblast become disseminated through the whole organism with the differentiated blood vessels and remain in specialized niches of the vascular wall as reserve adult stem cell population named pericytes (108). Additionally, evidence accumulate that the pericytes are the adult stem cells in the vertebrate organisms $(22,26,27)$. They are the ancestors of the mesenchymal stem cells (MSCs) $(22,28,100$, $109,147)$. 


\section{PERIENDOTHELIAL VERSUS PERIVASCULAR LOCATION OF THE STEM CELLS}

A real problem in the publications concerning not only the Leydig cells is the absence of the exact location of the presumed stem cells. It is not equal whether a cell has a periendothelial (embedded within the basement membrane of arterioles, capillaries and post-capillary venules and in contact with the endothelial cells) or perivascular position in the adventitia of the vessel wall (outside the basal lamina and being not in contact with the endothelial cells). In the first case the stem cell is situated in an authentic vascular niche $(15,24$, 110-112), whereas, the adventitia contains daughter cells of the vascular stem cells (the pericytes as ancestors) that proliferate, migrate, transdifferentiate and further, in the perivascular space ("stem cell niche of the vascular adventitia"; 78) and the distant interstitium, differentiate towards transit amplifying (51), immature and mature cells. This means that the pericytes are true pluripotent stem cells, whereas their progeny (transit amplifying cells) termed in the adventitia "mesenchymal stem cells" (MSCs or adventitial progenitor cells-APCs; 113, 114) are multipotent. Thus, in the vascular wall pericytes and endothelial cells coexist with MSCs both of which are interpreted by (115) as possibly progenies of adipose tissue-derived stem cells (ADSC) or more precisely as vascular stem cells (VSC) that are multipotent progenitor cells with reduced potency $(116,117)$. The capability of the transit amplifying cells, respectively the mesenchymal stromal cells to migrate away from the vascular adventitia (and/ or vascular tunica adiposa) explain the existence of extravascular, in addition to the perivascular positioned MSCs (114).

\section{PERICYTES OR MESENCHYMAL STEM CELLS (OR ACTUAL- LY, MULTIPOTENT MESENCHYMAL STROMAL CELLS)?}

A main problem is also that numerous authors do not make difference between pericytes and multipotent or mesenchymal stromal cells (MSCs) $(30,118-120)$. As mentioned, the pericytes have a periendothelial position, whereas the MSCs are situated perivascularly (218). Numerous studies postulate that pericytes and mesenchymal stromal cells (MSCs; until now dubbed mesenchymal stem cells) are the same cells or that all mesenchymal stem cells are pericytes $(22,24,26$, $27,52)$. This view is partially correct but there is now strong evidence that the pericytes are the ancestors of mesenchymal stromal cells $(22,24,27,48,121-124)$, because especially the earlier MSCs - descendants share close similarities with their pericyte ancestors. Pericytes are highly undifferentiated pluripotent cells (125) whereas the MSCs as more differentiated are multipotent. Furthermore a lot of authors interpret the existence or the absence of one or two marker substances as enough to define a different lineage of cells, which are in fact pericyte daughter cells in various stages of differentiation. There are results showing that the MSCs (APCs: adventitial progenitor cells) in cell culture conditions possess the capability to de-differentiate toward pericytes: "centripetal" relationship $(17,19,126)$. The reason for such events is the great plasticity of the stem cells appearing especially during experimental or pathological conditions.

\section{ARE THE PERICYTES STEM CELLS, PROGENITOR CELLS OR BOTH?}

The answer of this question provides some difficulties for the scientists to define the character of the ancestor cells, although in the literature these terms are clearly defined. Concerning the Leydig cells it is necessary to define their stem cells and their progenitors. As our studies demonstrate, the stem cells of the testicular Leydig cells are pericytes and smooth muscle cells of the microvasculature. From the view point that the pericytes are epiblast derivatives that at the beginning differentiate to pericyte, the pericytes are progenitor cells. Taking into account that pericytes are the representatives of the epiblast situated in the vascular niches, the conclusion is that they are adult stem cells with pluripotent qualities that are able to differentiate toward all tissues of the vertebrate body. Thus the pericytes are both stem and progenitor cells.

There is strong evidence that the pericyte progeny change the biochemical composition during its commitment to immature and further differentiation to adult, mature Leydig cells. The leading event is the process of fast transdifferentiation (127) in which the early progeny of the pericytes become transformed to transit amplifying cells, immature and mature Leydig cells that lose their similarities with the stem cell ancestors. This process affects also the potency of the stem/ progenitor cells.

It seems very likely that one of the earliest changes of the pericyte progeny in the testis is the expression of the PDGFR- $\alpha$, followed by the expression of other factors such as Coup - TFII, CD51, CD90, 3ß-HSD and additional enzymes involved in the process of steroidogenesis. These cells are correctly qualified as progenitor Leydig cells $(19,20)$ because these are migrating transit amplifying cells in process of maturation. However, in numerous publications they are qualified as stem cells (58). It is interesting to note that Kil- 
coyne et al (58) established that the Coup-TFII cells express also androgen receptors. This result provides additional evidence that the cells under study are differentiating progenitor cells and not stem cells.

\section{THE PERICYTES BEHAVE AS STEM CELLS. THEY ARE REST- ING IN AUTHENTIC MICROVASCULAR NICHES AND IF AC- TIVATED UNDERGO ALL CHANGES CHARACTERISTIC FOR TYPICAL STEM CELLS}

The pericytes behave principally as stem cells because, located in the vascular niches of various organs $(25,29,95$, $125,132-136)$, after activation, they self-renew and give rise to a large number of different cell types, including the Leydig cells. Thus, pericytes of the microvasculature, generally acting as stem/progenitor cells in the body, represent precursor cells in individual organs (nervous system, muscle, skeleton, skin, liver, testis), where they generate population of restricted progenitor, intermediate and differentiated adult organspecific cells (137-140).

After activation the pericytes self-renew, proliferate, migrate, disrupt the vessel basal membrane, leave the stem cell niche and as transit amplifying daughter cells enter the perivascular space $(14,33)$ and transdifferentiate to provide committed young (immature) Leydig cells. From the moment in which a daughter cell of the divided pericytes enter the perivascular space, it becomes transit amplifying cell (51), that still possess some pericyte markers, but under the influence of the chemical composition and factors of the perivascular space, rapidly prolongs to differentiate, changes its gene activity and becomes a different phenotype that may do not have any similarity with its ancestor. So there is the possibility that the early changes from the resting pericyte state starts still in the microvascular niche after the activation and proliferation of the stem cell, depending on its dislocation within the niche at the beginning of its migration, as described for the skin bulge stem cells by (111). Some of the activated pericytes become microvascular smooth muscle cells (myofibroblasts), thus pericytes and smooth muscle cells share a common lineage and the unified term pericytes or mural cells is used more often $(29,30,126)$. Now, it becomes evident that the pericytes are the periendothelial adult stem cells (e.g. the Leydig stem cells) whereas they progeny, the transit amplifying cells represent the perivascular progenitor cells (e.g. the Leydig cell progenitors). To avoid some confusing interpretations Lin and Lue (141) suggest the term vascular stem cells (VSCs) as a more accurate term for mes- enchymal stem cells (MSCs). This term includes both the periendothelial pericytes and the adult perivascular/adventitial stem/progenitor cells (APCs). This is important because the most experimentally isolated and cultured mesenchymal stem cells consist of a mixture of both: pericytes and adventitial stem/progenitor cells.

"Multipotent stem cells", partially cells of the vascular endothelium, were firstly mentioned by Friedenstein et al $(142,143)$. According to (17) because of their high heterogeneity the MSCs have been re-named "multipotent mesenchymal stromal cells" modifying the term "stem" into "stromal" in order to maintain the same acronym and avoid possible over-interpretation of their limited pluripotent potential (121, $144,145)$. Recently (17) defined a new perivascular cell population the "multipotent stromal cells" (MSCs). Before that, these authors described the "mesodermal progenitor cells" (MPCs) as a subpopulation of the MSCs $(103,104)$. Petrini et al (103) describe these cells as peculiar large cells, which show embryonic markers, high aldehyde dehydrogenase activity (ALDH) activity, and the potential to differentiate into several mesodermal lineages including mesenchymal and endothelial cells and identify them as "mesodermal progenitor cells" (MPCs). The MPCs do not show features of pericytes and adventitial progenitors. However, that's not the case in the testis, because the pericytes express both Nestin and CD31/PECAM and exactly as the described MPCs lose these markers with their further differentiation and are involved in angiogenesis. Moreover, there is evidence that MPCs act as pericytes within experimental tumors $(146,147)$.

In addition, only cultured pericyte progenitors and not MSCs in culture are highly immature cells with increased plasticity that yielded neuronal differentiation potential (116, 148). Furthermore, only pericytes, but not MSCs, have the capability to migrate through a mimetic basement membrane and to interact with endothelial cells for stabilization of the tubular vascular structures $(33,149)$. However, (13) and (149) emphasized, that a controversy remains, as the MSCs don't express several molecular markers specific to the pericytes such as PDGFR- $\beta$ (platelet-derived growth factor receptor- $\beta$ ), desmin, NG2 (chondroitin sulfate proteoglycan 4 ), and $\alpha$-SMA ( $\alpha$-smooth muscle actin) which suggests the existence of cell functions specific only to pericytes or to MSCs, despite the shared markers between these cell types. In this respect, it must be noted, that the MSC are transit amplifying cells which are in process of differentiation leading to changes in the marker expression characteristic for the 
pericytes. This shows that the similarity between the ancestor cells and the daughter cells disappear with the progression of their maturity. However, for the pericytes and the Leydig cells there is one exception because the Leydig cells retain the neural markers also in their mature state $(14,15)$. In addition, the MSCs, as progeny of the pericytes, are multipotent and not pluripotent like their ancestors. In contrast to pericytes, there is no clear evidence for transdifferentiation capacity of MSCs (121).

However, recently published results do not agree with the notion that the pericytes are stem cells $(119, \mathrm{cf} .120)$. These authors (119) admit that their conclusion concerns only the organs under their investigation (brain, heart, tibialis anterior skeletal muscle, and multiple adipose depots) and make sure that in other organs this may be not the case. In this respect, we evidenced that the ancestors of the Leydig cells are the microvascular pericytes (14). This was confirmed in experiments with ectopically autografted adult mouse testes by (9). Also for other organs it was shown that the pericytes play the role of adult stem cells. As Cano et al (120) underline, the main problem in the study of (119) is the unsatisfactory distinction of the pericytes and the mesenchymal stem cells. In this respect our results and the results of other authors (22, $26,149,150)$ show that the pericytes and the mesenchymal stem cells possess very high similarity in expressing stem and progenitor cell marker molecules. Detailed interpretation allows the conclusion that the pericytes are the ancestors of the mesenchymal stem cells (paper under preparation). The MSCs are a product of the proliferating and migrating pericytes. Under the influence of local factors the early transit amplifying cells undergo a fast transdifferentiation and convert towards multipotent, premature (intermediate, young) cells which gradually lose any morphological, biochemical and functional relationship (similarity) with their ancestors (219-221) and differentiate further as typical for the organ mature cells $(14,15,151)$.

\section{POTENCY OF THE STEM/PROGENITOR CELLS}

The pericyte progenitors together with the primitive (primordial) germ cells and the hematopoietic stem cells are the earliest lineage descendants of the epiblast $(41,42)$.

The true adult stem cells are pluripotent. Beside the primordial germ stem cells, the only effective pluripotent adult stem cell phenotype in the differentiating and adult organism is the pericyte (41).

A lot of authors do not describe precisely the pluripotent

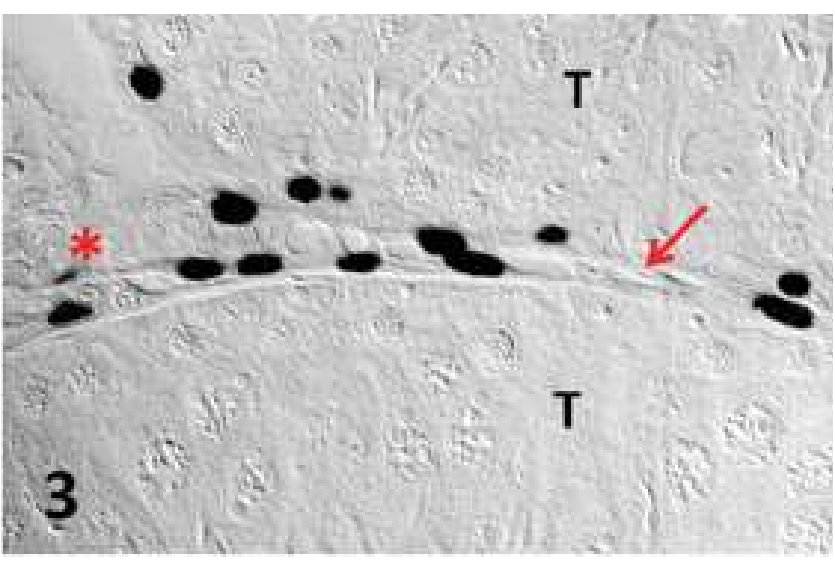

Figure 3. Bromodeoxyuridine (BrdU) in rat pericyte nuclei 2 days after EDS injection. The capillary is designated by the red asterisk and the arrow. Note the close relationship between the vessel/pericytes and the tubules (T) walls. X 550

or multipotent qualities of the members of a cell lineage as well as the restriction of the potency of a perivascular daughter progenitor cell during its further differentiation. It have to be noted that the pericytes behave as pluripotent stem cells $(25,35,125)$, whereas the MSCs are multipotent and with their further differentiation they lower the potency becoming oligopotent and unipotent $(22,27)$. Thus MSCs are the progeny (the daughter cells) of the activated, proliferated and migrating pericytes. Consequently, pericytes represent in fact the true adult stem cells of the vertebrate organism. Only the pericytes lie within authentic vascular niches and are able to disrupt the basal lamina and migrate toward the interstitium of an organ $(33,149,152-154)$. In accordance with this explanation, MSCs represent the transit amplifying cells of the transdifferentiated pericytes, which as progenitors differentiate further to premature and mature somatic cells with a changed phenotype. Altogether, MSCs are pericyte-derived multipotent progenitor cells.

\section{THE HISTOLOGY (MICROSCOPIC SHAPE) OF THE ADULT STROMAL STEM CELLS}

Numerous authors use the histological shape of a cell as criterion for the determination of its phenotype or cell lineage. Accordingly, the Leydig stem cells have been described as interstitial or peritubular elongated fibroblast-like or small spindle-shaped cells with mesodermal origin $(55,63,64,66$, $155,156)$. It is actually like that the Leydig cell progenitors are spindle-shaped. However, these scientists have ignored the fact that the activated pericytes are also spindle-shaped, 


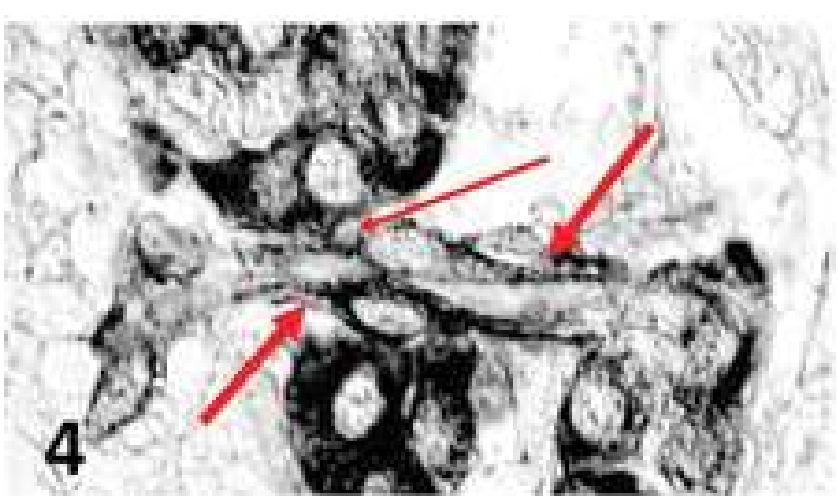

Figure 4. Nestin immunoreactivity in activated pericytes 14 days after EDS application. Note the spindle shaped form of the pericytes on the capillary wall (thick arrows). The migrating pericytes form aggregates in the vicinity of the vessels. Some pericytes have still contact with the vessel wall (thin arrow). $X 950$

regardless of that they are derivatives of the pluripotent epiblast cells (Fig. 4, 5). Moreover, the space orientation of the stem, progenitor and Leydig cells depends to a great extend from the orientation (intertubular or peritubular) of the testicular blood vessels. In this respect (97) and (60) showed that the testis vasculature (especially the endothelial cells) is responsible during embryogenesis to organize the position of the seminiferous tubules with which they are in very close contact. Our study on the postnatal development of Leydig cells in the rat testis has shown that even on the $60^{\text {th }}$ postnatal day the differentiating Leydig cells are spindle-shaped and keep the contact with the blood vessels via their long processes that also cover the surface of the microvasculature (14, 15). Probably this relation is retained during the whole life (Fig.5). As seen in the Figure, in cross or bevel sections the Leydig cell bodies appear round or oval.

It is interesting to note that the peritubular localization of new, from the vessel wall arising, Leydig progenitor cells, after ethane dimethanesulfonate (EDS) destruction of the original Leydig cell population (Fig. 6), depends on the distribution and orientation of the peritubular vessels that supply two neighboring tubules (Fig. 3). In this respect it is very probable that the Leydig progenitor cells become in their further differentiation influences from regulatory signals of the tubular structures (Sertoli cells, germ cells, and myofibroblasts of the lamina propria) (Fig. 3-7) and of the microenvironment that determine their migration, proliferation and differentiation $(19,20,25)$. The close contact between the peritubular capillaries and the seminiferous tubules make it indeed difficult to determine whether cells of lamina propria or cells of vascular wall are stem cells. However, our results show unequivocally that the stem cells are pericytes and smooth muscle cells of the microvasculature and that the cells surrounding the seminiferous tubules are their progeny in form of early migrating Leydig cell progenitors (partially transit amplifying cells; 14, 15) expressing steroidogenic factors. At one established period of the testis development the peritubular immature Leydig cells reduce in number, become atrophic or destroyed. In some publications this phenomenon is explained with back

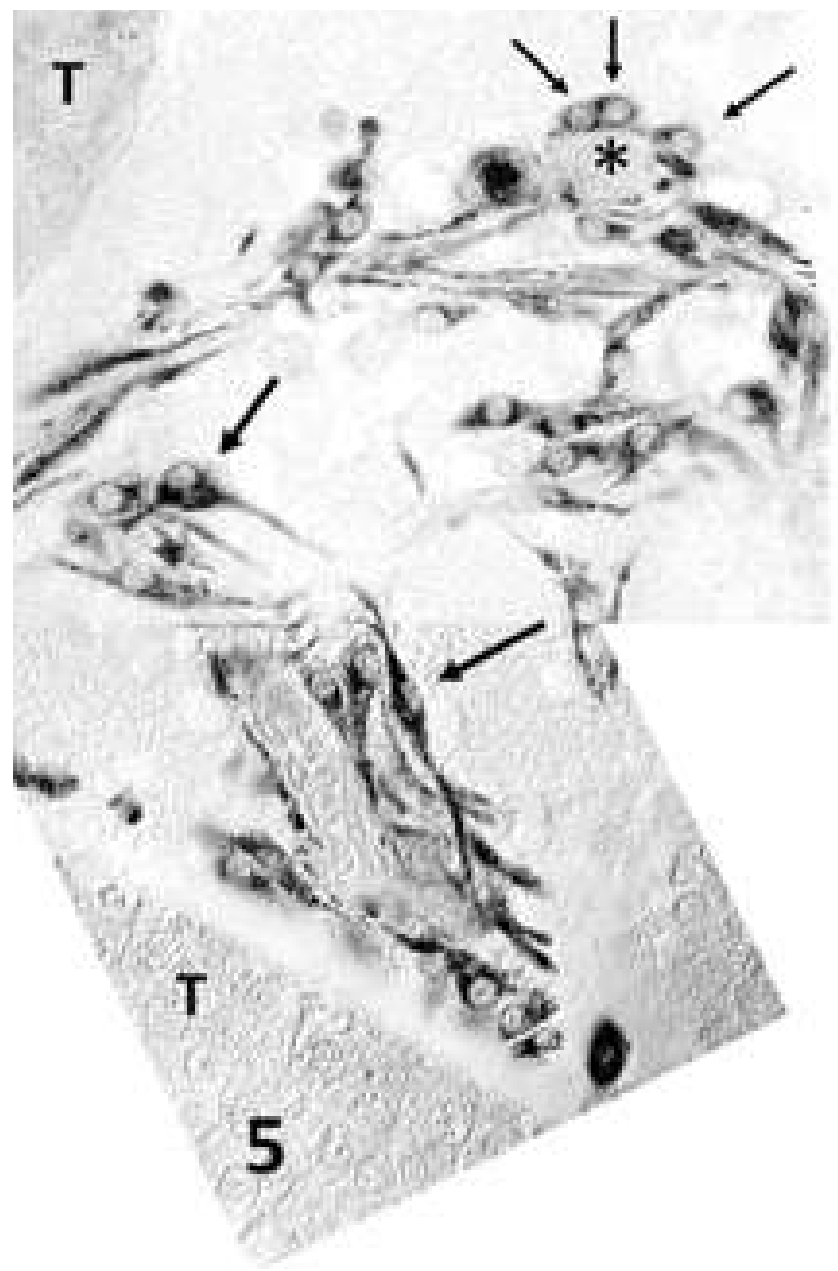

Figure 5. Photo montage of Rat testis interstitium. Cytochrome P450 cholesterol side chain cleavage enzyme (CytP450scc) immunoreactivity on day 60 of postnatal development. Numerous positive young (immature) Leydig cells possess spindle-shaped form (large arrows). Their outgrowths show contacts with the vessel walls or cover the walls over long distances. The bodies of cross-sectioned Leydig cells in contact with the vessel (asterisk) are round or oval (small arrows). $T$-tubules. $X 380$ 
migration of these cells toward and accumulation within the interstitial space of the testis. It seems more likely that at this time of the fetal development fewer hormones are needed for the composition, maintenance and functioning of the seminiferous tubules which leads to the dedifferentiation, atrophy and disappearance of the unnecessary cells. As consequence the interstitial perivascular cells increase in number and become enlarged. They remain in contact with the blood vessel wall (Fig.5) and supply hormones for the male forming organism.

\section{THE PERICYTES AND THE LEYDIG CELLS ARE NOT PROGENY OF THE NEURAL CREST}

To explain some events with the pericytes and keeping in mind that the Leydig cells possess neural properties, we used information concerning the situation in the central nervous system. As mentioned above there is a great similarity between the biology of the developing and adult Leydig cells and the progenitors /immature/mature nerve and glial cells. Also in the nervous system until recently the brain vasculature/pericytes were neglected. However, the first evidence was provided by Palmer et al (95) which found that adult neurogenesis occurs within an angiogenic niche (222). Later it becomes evident that in the telencephalon a very well developed subventrucular vascular plexus exists $(157,158)$ and the theory on the neurovascular unit was broadly accepted $(159,160,161)$. According to (162) pericytes and astrocytes play important role for the maintenance of the cerebral microvasculature. In this respect, it seems very probable that the brain microvascular pericytes possess the capability to transdifferentiate into radial astroglia (163-166). Thus the conclusion can be made that the pericytes of the subventricular plexus are the neural stem cells (174) which generate the B progenitors (GFAP+ astrocytes; radial glia), that build the $\mathrm{C}$ (transit amplifying) cells and the A (neuroblast) cells which are surrounded by an glial tunnel that lead them towards the olfactory bulb (167-169). This hypothesis is also supported by the observation that Nestin and NG2-positive cells are precursors of neurons, oligodendrocytes and astrocytes in the gray matter $(170,171)$. Similar conditions were reported for the subgranular zone of the hippocampal dentate gyrus (164, 172, 216; Fig. 9).

As evidenced both the pericyte progenitors and the neural crest stem cells (NCSCs) represent very early phenotypes in the embryogenesis which show remarkable similarities in their expression activities $(21,23,42)$. This was the reason for the presumption that both cell types originate from the same earlier ancestor. The similarity between the NCSCs and the pericytes is an unequivocal fact $(1,10,173$. 175-178) what allowed to determine the Leydig cells as neuroendocrine cells and lead to the presumption that the pericytes, resp. the Leydig cells are of neural crest origin_(14, 15, 52). However, we were convinced by new results (see below) that the reason for this similarity is the close embryologic timing in arising of these cell types (Fig. 1).

Consequently, the neural crest cells arise at the border of the neural plate and the epidermis at the time of neural tube closure $(179,180)$. As new data show, in the embryonic ectoderm of the neural fold two different cell populations coexist: authentic neural crest cells and mesectodermal stem cells (181-183). The neural crest cells, derived from the epiblast/ ectoderm possess some restricted multipotent characteristics and represent a migratory cell population that generates diverse cell types during vertebrate development (184-186). In comparison, the pericytes originate something earlier direct from the epiblast whereas the neural crest stem cells arise a bit later from the primary germ layer, the ectoderm, which is also a derivate of the epiblast (epiblast/ectoderm; Fig. 1). In this respect (187) reveal that the epiblast cells possess different transcriptomes in comparison with the epiblast/ectoderm. Thus NCSCs arise indirectly from the epiblast and as recent results show they are not pluripotent, but multipotent and are able to produce different cell types with neural qualities, but not mesenchymal cells $(4,83,183,223,224)$.

There is also evidence that the neural crest cells cannot produce pericytes $(9,83,102,182,183,188)$. Therefore the only way that remains is that the pericytes are the progeny of the epiblast whereas the neural crest is the daughter structure of the a bit later arising epiblast/ectoderm (42). Thus, the epiblast arises a little earlier from the ICM (189) than the epiblast-derived germ line, the ectoderm, which is the ancestor of the neural crest (190). The mesenchymallike cells are product of a sharp from the neural crest stem cells bordered cell group in the neural fold (non-neural epithelial domain: (191). These cells possess the ability to perform an epithelial-to-mesenchymal transition and were termed metablast $(9,181-183,191,192)$ or ectomesenchyme (mesectoderm). As Weston et al (182) show, within the neural fold, a sharp boundary exists between Ecadherin-expressing non-neural epithelium and the neural epithelium of the dorsal ridge. In addition, they found that cells co-expressing E-cadherin and PDGFR $\alpha$ are present in the non-neural epithelium of the neural folds. These observations raise the possibility that at least some PDGFR $\alpha$ 
ectomesenchyme originates from the lateral non-neural domain of the neural fold epithelium. This seems to be consistent with previous reports (193, 194) that mesenchymal cells emerge precociously from an epithelial neural fold domain resembling the primitive streak in the early embryonic epiblast. The authors underline their hypothesis that neural crest and ectomesenchyme are developmentally distinct progenitor populations and that at least some ectomesenchyme is metablast-derived rather than neural crest-derived tissue. It was also found that the pericytes and the endothelial cells are not neural crest derivatives (102). We presume that the
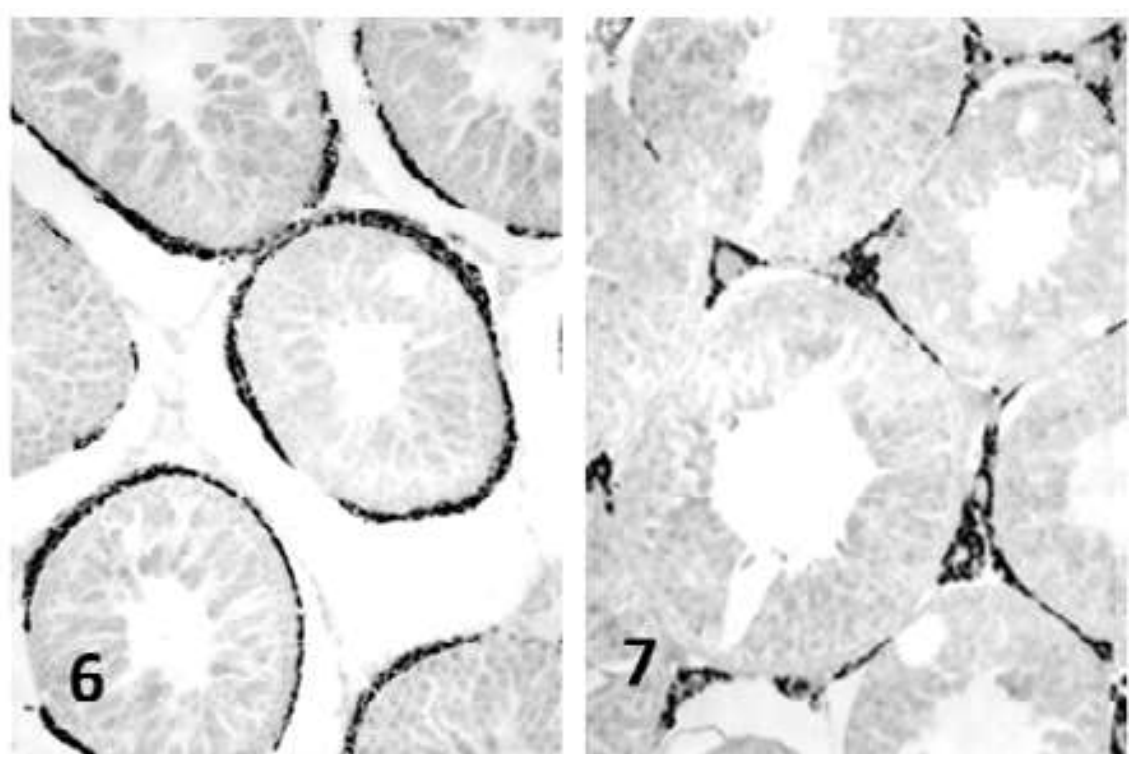
described metablast cells are of epiblast origin and resemble pericyte precursors.

Of note, the neural crest cells arise and migrate after the origin of the developing vasculature and use the blood vessels and the associated extracellular matrix as leading structures (195). Thus, the pericytes are disseminated before the migration of the neural crest stem cells and are not produced by them. With other words the pericytes, resp. the Leydig cells are not neural crest derivatives.

\section{THE PERICYTES AND THE PERITUBULAR MYOID CELLS}

There is strong evidence that during normal development and after EDS treatment, new Leydig cells can be seen in peritubular position as sheaths surrounding the seminiferous tubules (15; Fig. 6, 7). A number of authors presume that these Leydig cells arise from the peritubular myoid cells (196, 197). However, some of the authors designate these cells as Leydig cell progenitors (PDGF-A positive) that is more accurate (59). Studies concerning the testis development describe that the peritubular myoid cells are interstitial stromal cells that are attracted by the Sertoli cells, both building the basal membrane that stabilize the differentiating seminiferous tubules. We presume that the peritubular myoid cells are also pericyte progeny $(198,199)$. As mentioned the activated pericytes build myofibroblasts under different physiological and pathological circumstances (200-202). After the seminiferous tubules become created, developing Leydig cells in form of transit amplifying cells become attracted, to build an additional fetal type Leydig cell sheath around the tubules which

Figure 6, 7. Immunoreactivity for CytP450scc in young rat Leydig cells on day 21 and 30 after EDS. Note the massive peritubular accumulation (Fig. 6) and the lowering the number of the positive peritubular cells on day 30 (Fig. 7). X450

provide the tubules and the peritubular myoid cells with hormones necessary for the final differentiation of the tubular structures. The close relationship between the blood vessels and the seminiferous tubules provide the best conditions for exchange and influence of substances. Thus, the migrating pericyte progeny move along the peritubular vessels and remain in contact with the tubular surface after being attracted and linked by the Sertoli cells and the peritubular myofibroblasts. In this respect, the Sertoli cells, the peritubular myoid cells and the Leydig progenitor cells exchange signals that regulate these events. The most important among them are PDGF-proteins and their receptors, the androgen receptors and some other factors. For example, it was reported that in the rat fetus PDGF-A expression corresponds with the rapid proliferation (59, 203 in fetal and adult human testis) and the testosterone expression of the Leydig cells. PDGFs were demonstrated in rat Sertoli cells which chemoattract PDGFRexpressing peritubular myoid cells (PMCs) in close proximity of the seminiferous tubules (204, 205). Mariani et al (206) found that PDGF-B/PDGFR- $\beta$ interactions may be involved in the proliferation and migration of peritubular myoid cell (PMC) precursors from the intertubular space to the peritubulum. Ergün et al $(87,99)$ provide evidence that endothelin (ET) produced in Leydig and Sertoli cells can act in a paracrine manner via ET-B receptors in the human testicular mi- 


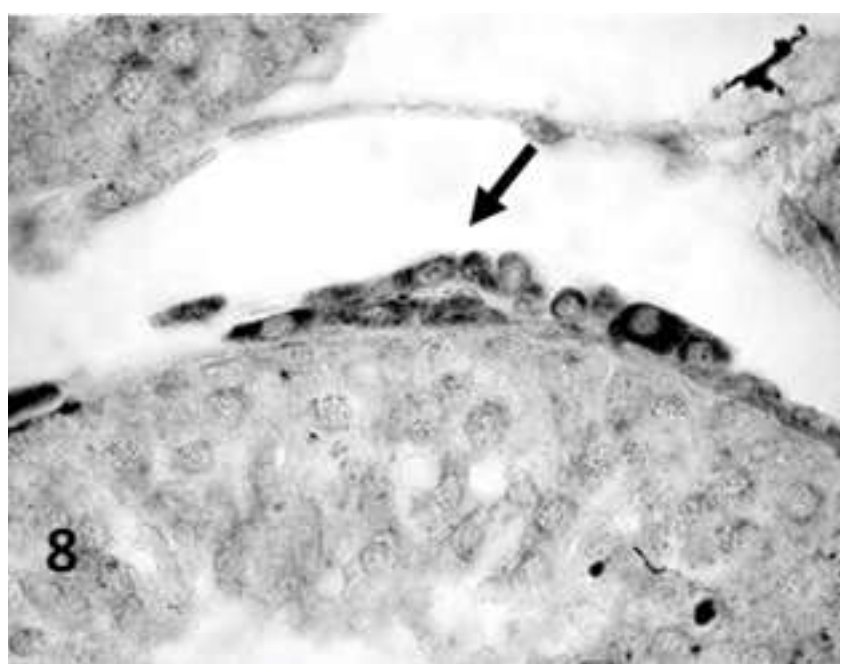

Figure 8. Fragment of a seminiferous tubule of a rat testis on day 30 after EDS treatment. The arrow points to a young Leydig cell accumulation showing ubiquitin immunoreactivity. The cells surround a small peritubular capillary (arrow). X 500

crovasculature and the peritubular myofibroblast. In addition, (98) found in lamina propria of human testis intramural vessels which are partly fenestrated and possess pericytes. This seems to be partially true for the rat testis in which after EDS treatment accumulation of peritubular regenerating Leydig cells around capillaries closely associated with tubules were observed (Fig. 8; 14, 15). Earlier study provide evidence that the testicular pericytes are PDGFR- $\alpha$ and PDGFR- $\beta$ positive and that at 1 week of postnatal development spindle-shaped cells in the testicular interstitium, positive for PDGFR- $\alpha$, differentiate to adult Leydig cells which become immunoreactive for all PDGFs and their receptors (197).

Concerning the androgen receptors (AR) it was shown that testicular AR mRNA exists in Leydig cells, pericytes, peritubular myoid cells, and Sertoli cells (207). The Leydig cells are maximally sensitive to androgen during puberty, which is consistent with the hypothesis that androgens facilitate their differentiation. As mentioned, Kilcoyne et al (58) found that the interstitial Leydig cell progenitors express androgen receptors (44). It was also established that the androgen action via testicular peritubular myoid cells (PMC) is essential for normal testis function, spermatogenesis, and fertility in males (208). Moreover, the androgen action via smooth muscle cells of testicular arterioles is important for Leydig cell differentiation, function, vasomotion and fluid dynamics $(209,210)$. In this respect, (211) presume that tes-

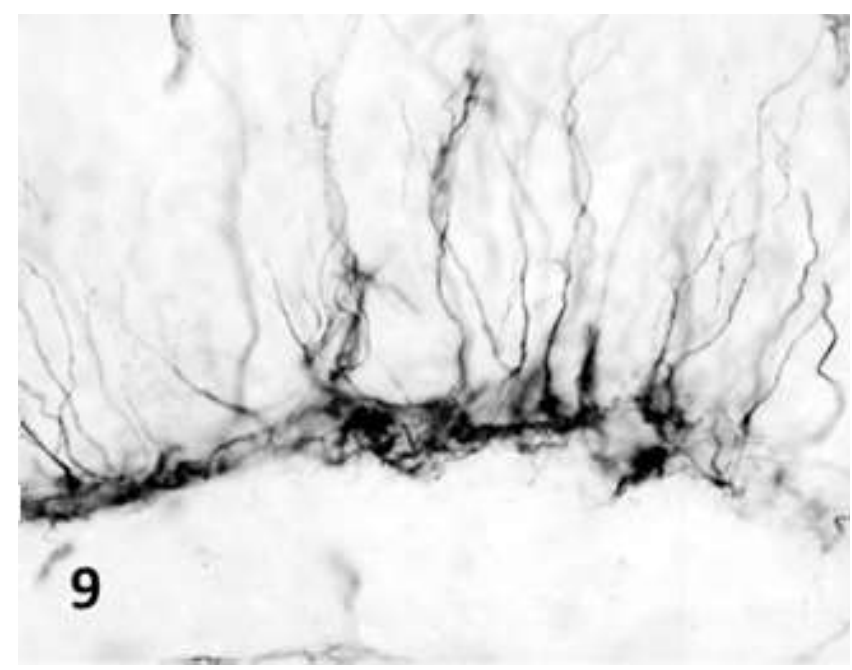

Figure 9. Nestin immunoreactivity in the subgranular zone of the mouse hippocampal dentate gyrus. The positive stem cells show great similarity with the radial glia of the cerebral cortex. These cells have a close contact with the microvasculature of this zone. X 300

ticular blood vessels could be a target-organ for androgens and may mediate some of the effects of androgens in the testicular microcirculation. It was also found that the suppression of AR elevates the EGFR (epidermal growth factor receptor) and enhances the self-renewal of the MSCs (212). Peritubular myoid cells contain ARs and are involved in retinol processing, which is important for the maintenance of the spermatogeneis (196). There is also no convincing proof that the PMCs are the Leydig stem cells.

In conclusion, the peritubular myofibroblasts may be also derived by the pericyte transit amplifying cells. In combination with the Sertoli cells the PMC become peritubular cells that are important for the differentiation of the seminiferous tubules and the steroidogenesis of the newly arising Leydig cells as well as for the fetal microcirculation. Important significance for these processes seems to have PDGFs and their receptors, also ARs and COUP-TFII and its receptor H3K27me3 $(56,58)$. The PTM-AR signaling is important for normal development, ultrastructure, and function of the adult Leydig cells $(44,205$, 208, 209, 214; 215 - in human adrenals).

\section{CONCLUDING REMARKS}

Until now four main sources of the testicular Leydig cells were presumed, namely the mesenchymal stromal cells, the peritubular myofibroblast cells, the neural crest stem cells, and the pericytes. New results provide evidence that the neu- 
ral crest stem cells and the peritubular myofibroblast are not able to produce Leydig cells. As the most realistic source remain the pericytes and the smooth muscle cells of the testis microvasculature. Thus, the pericytes are the only effective adult pluripotent epiblast derivative that produces the neuroendocrine Leydig cells of the testis. The pluripotent epiblast cells migrate with the very early developing vasculature and become disseminated and stored throughout the whole organism as pericytes within authentic vascular niches and remain as a pluripotent resting (reserve) adult stem cell population for tissue generation, maintenance, repair or regeneration of different morphologically and functionally cell phenotypes, depending on the existing environmental factors. The neural features of the Leydig cells are result of their origin from the pluripotent epiblast derivatives and not from the neural crest. The similarity between the neural crest stem cells and the Leydig cells is based on the close timing of their origin in the early embryogenesis.

The Leydig cells are so far not neural crest and peritubular myoid cells progeny. The peritubular myofibroblasts, together with the Sertoli cells, contribute for the seminiferous tubules differentiation and the steroidogenic differentiation and function of the Leydig cell progenitors. Finally, the pericytes are the ancestors of the migrating perivascular and mesenchymal stromal cells (until now termed mesenchymal stem cells). Some cells of these populations may possibly de-differentiate "centripetal" to pericytes only under special (experimental or pathological) conditions. Actually, the mesenchymal stromal cells are transit amplifying cells of the activated pericytes that further differentiate toward cell types characteristic for the tissue or organ in which they are situated.

The exact knowledge of the nature and functions of the stem cells and their progeny is of great importance of the understanding of the genesis of a normal organism and the mechanisms of development of a pathological conditions, and raises new ideas in the field of practical medicine.

\section{CONFLICT OF INTEREST STATEMENT}

The author certifies that he has no affiliations with or involvement in any organization with any financial interest in the subject matter discussed in this review article.

\section{REFERENCES}

1. Schulze W, Davidoff MS, Holstein A-F. Are Leydig cells of neural origin? Substance P-like immunoreactivity in human testicular tissue. Acta Endocrino- logica (Copenh) 1987; 115: 373-377. DOI: 10.1530/ acta.0.1150373

2. Davidoff MS, Schulze W, Middendorff R, Holstein A-F. The Leydig cell of the human testis - a new member of the diffuse neuroendocrine system. Cell Tiss Res 1993; 271: 429-439.

3. Davidoff MS, Middendorff R, Holstein AF. Dual nature of Leydig cells of the human testis. Biomed Rev 1996; 6: 11-41.

4. Ortega HH, Lorente JA, Salvetti NR. Immunohistochemical study of intermediate filaments and neuroendocrine marker expression in Leydig cells of laboratory rodents. Anat Histol Embryol 2004; 33: 309-315 DOI: 10.1111/j.1439-0264.2004.00559.x

5. Ortega HH, Lorente JA, Mira GA, Baravalle C, Salvetti NR. Constant light exposure causes dissociation in gonadotrophin secretion and inhibits partially neuroendocrine differentiation of Leydig cells in adult rats. Reprod Domest Anim 2004; 39: 417-443. DOI: 10.1111/j.1439-0531.2004.00541.x

6. Ortega HH, Salvetti NR, Baravalle C, Lorente JA, Mira GA. Oestradiol induced inhibition of neuroendocrine marker expression in Leydig cells of adult rats. Repr Dom Anim 2006; 41: 204-209.

7. Foster K, Sheridan J, Veiga-Fernandes H, Roderick $\mathrm{K}$, Pachnis V, Adams R, et al. Contribution of neural crest-derived cells in the embryonic and adult thymus. J Immunol 2008; 180: 3183-3189. DOI: 10.4049/jimmunol.180.5.3183

8. Gong Y-G, Feng M-M, Hu X-N, Wang Y-Q, Gu M, Zhang $\mathrm{W}$, et al. Peptidergic not monoaminergic fibers profusely innervate the young adult human testis. $J$ Anat 2009; 214: 330-338. DOI: 10.1111/j.14697580.2008.01038.x

9. Makala H, Pothana L, Sonam S, Malla A, Goel S. Regeneration of Leydig cells in ectopically autografted adult mouse testis. Reproduction 2015; 149: 259-268. DOI: 10.1530/REP-14-0576.

10. Benton L, Shan L-X, Hardy MP. Differentiation of adult Leydig cells. J Steroid Biochem Mol Biol 1995; 53: 6168.

11. Ge R-S, Dong Q, Sottas CM, Papadopoulos V, Zirkin BR, Hardy MP. In search of rat stem Leydig cells: identification, isolation, and lineage-specific development. Proc Natl Acad Sci USA 2006; 103: 2719-2724. DOI: 10.1073/pnas.0507692103

12. Tang H, Brennan J, Karl J, Hamada Y, Raetzman L, 
Capel B. Notch signaling maintains Leydig progenitor cells in the mouse testis. Development 2008; 135: 3745-3753. DOI: 10.1242/dev.024786

13. Armulik A, Genové G, Betsholtz C. Pericytes: developmental, physiological, and pathological perspectives, problems, and promises. Dev Cell 2011; 21: 193-215. DOI: 10.1016/j.devcel.2011.07.001

14. Davidoff MS, Middendorff R, Enikolopov G, Rietmacher D, Holstein AF, Müller D. Progenitor cells of the testosterone-producing Leydig cells revealed. J Cell Biol 2004; 167: 935-944. DOI 10.1083/jcb.200409107

15. Davidoff MS, Middendorff R, Müller D, Holstein AF. The Neuroendocrine Leydig Cells and their Stem Cell Progenitors, the Pericytes. Adv Anat Embryol Cell Biol 2009; 205: 1-154. DOI 10.1007/978-3-642-00513-8

16. da Silva Meirelles L, Chagastellesd PC, Nardi NB. Mesenchymal stem cells reside in virtually all postnatal organs and tissues. J Cell Sci 2006; 119: 2204-2213. DOI: $10.1242 /$ jcs.02932

17. Pacini S, Petrini I. Are MSCs angiogenic cells? New insights on human nestin-positive bone-marrow-derived multipotent cells. Front Cell Dev Biol 2014; 2, Article 20. DOI: 10.3389/fcell.2014.00020. eCollection 2014

18. Liu C, Rodriguez K, Yao HH. Mapping lineage progression of somatic progenitor cells in the mouse fetal testis. Development 2016; 143: 3700-3710. DOI: 10.1242/dev.135756

19. Chen H, Wang Y, Ge R, Zirkin BR. Leydig stem cells: identification, proliferation and differentiation. Mol Cell Endocrinol 2017; 445: 65-71. DOI: 10.1016/j. mce.2016.10.010.

20. Ye L, Li X, Li L, Chen H, Ge R-S. Insights into the development of the adult Leydig cell lineage from stem Leydig cells. Front Physiol 2017; 8:430. DOI: 10.3389/ fphys.2017.00430

21. Zwaka TP, Thomson JA. A germ cell origin of embryonic stem cells? Development 2005; 132: 227-233. DOI: 10.1242/dev.01586

22. Crisan M, Yap S, Casteilla L, Chen C-W, Corselli M, Park TS, Andriolo G, et al. A perivascular origin for mesenchymal stem cells in multiple human organs. Cell Stem Cell 2008; 3: 301-313. DOI: 10.1016/J. Stem.2008.07.003

23. De-Miguel MP, Fuentis-Julian S, Alcaina Y. Pluripotent stem cells: origin, maintenance and induction. Stem Cell Rev and Rep 2010; 6: 633- 6409. DOI: 10.1007/ s12015-010-9170-1
24. Collas P. Programming differentiation potential in mesenchymal stem cells. Epigenetics 2010; 5: 476-482. DOI: 10.4161/epi.5.6.12517

25. Dore-Duffy P. Pericytes: pluripotent cells of the blood brain barrier. Curr Pharm Des 2008; 14:1581-1593. DOI: $10.2174 / 138161208784705469$

26. Caplan P, Robey PG, Simmons PJ. Mesenchymal stem cells: revisiting history, concepts, and assays. Cell Stem Cells 2008; 2:313-319. DOI: 10.1016/j. stem.2008.03.002.

27. Caplan AI. All MSCs are pericytes? Cell Stem Cell 2008; 3:229-230. DOI: 10.1016/J.Stem.2008.08.008

28. Chen H, Ge R-S, Zirkin BR. Leydig cells: From stem cells to aging. Mol Cell Endocrinol 2009; 306: 9-16. DOI:10.1016/j.mce.2009.01.023

29. Péault B. Are mural cells guardians of stemness? From pluri- to multipotency via vascular pericytes. Circulation 2012; 125:12-13. DOI: 10.1161/CIRCULATIONAHA.111.073445

30. Özen I, Boix J, Paul G. Perivascular mesenchymal stem cells in the adult human brain: a future target for neuroregeneration? Clin Translat Med 2012; 1(1):30. DOI: 10.1186/2001-1326-1-30.

31. Kucia M, Wu W, Ratajczak MZ. Bone marrow-derived very small embryonic-like stem cells: their developmental origin and biological significance. Dev Dynam 2007; 236:3309-3320. DOI: 10.1002/dvdy.21180

32. Kucia M, Wysoczynski M, Ratajczak J, Ratajczak MZ. Identification of very small embryonic like (VSEL) stem cells in bone marrow. Cell Tiss Res 2008; 331:125134. DOI: $10.1007 / \mathrm{s} 00441-007-0485-4$

33. Dore-Duffy P, Owen C, Balabanov R, Murphy S, Beaumont T, Rafols JA. Pericyte migration from the vascular wall in response to traumatic brain injury. Microvasc Res 2000; 60: 55-69

34. Dore-Duffy P, Katychev A, Wang X, Buren EV.. CNS microvascular pericytes exhibit multipotential stem cell activity. J Cerebral Blood Flow Metab 2006; 26: 613-624. DOI: 10.1038/Sj.Jcbfm.9600272

35. Dore-Duffy P, Mehedi A, Wang X, Bradley M, Trotter R, Gow A. Immortalized CNS pericytes are quiescent smooth muscle actin-negative and pluripotent. Microvasc Res 2011; 82: 18-27. DOI:10.1016/j. mvr.2011.04.003

36. Suwinska A, Ciemerych MA. Factors regulating pluripotency and differentiation in early mammalian embryos and embryo-derived stem cells. Vitamins and 
Hormones 2011; 87: 1-37 DOI: 10.1016/B978-0-12386015-6.00022-6

37. Kucia M, Machalinski B, Ratajczak MZ. The developmental deposition of epiblast/germ cell-line derived cells in various organs as a hypothetical explanation of stem cell plasticity? Acta Neurobiol Exp 2006; 66: 331-341

38. Ratajczak MZ, Zuba-Surma EK, Wysoczynski M, Ratajczak J, Kucia. Very small embryonic-like stem cells: Characterization, developmental origin, and biological significance. Exp Hematol 2008; 36: 742-751. DOI: 10.1016/j.exphem.2008.03.010

39. Ratajczak MZ, Shin D-M, Liu R, Mierzeiewska K, Ratajczak J, Kucia M, et al. Very small embryonic/epiblast-like stem cells (VSELs) and their potential role in aging and organ rejuvenation - an update and comparison to other small stem cells isolated from adult tissues. Aging 2012; 4: 235-246. DOI: 10.18632/aging.100449

40. Ratajczak MZ, Zuba-Surma E, Kucia M, Poniewierska A, Suszynska M, Ratajczak J. Pluripotent and multipotent stem cells in adult tissues. Adv Med Sci 2012; 57: 1-17. DOI: 10.2478/v10039-012-0020-z

41. Montiel-Eulefi E, Sánchez R, Rojas M, Bustos-Obregon E. Epiblast embryo stem cells give origin to adult pluripotent cell populations: primordial germ cell, pericytic and haematopoietic stem cells. A review. Int J Morphol 2009; 27: 1325-1333

42. De-Miguel MP, Arnalich-Montiel F, Lopez-Iglesias P, Blasquez-Martinez A, Nistal M. Epiblast-derived stem cells in embryonic and adult tissues. Int J Dev Biol 2009; 53:1529-1540. DOI: 10.1387/ijdb.072413md

43. Suwinska A, Czolowska R, Ozdzenski W, Trakowski AK. Blastomeres of the mouse embryo lose totipotency after the fifth cleavage division: Expression of $\mathrm{Cdx} 2$ and Oct4 and developmental potential of inner and outer blastomeres of 16- and 32-cell embryos. Dev Biol 2008; 322:133-144. DOI:10.1016/j.ydbio.2008.07.019

44. Shan L-X, Hardy MP. Developmental changes in levels of luteinizing hormone receptor and androgen receptor in rat Leydig cells. Endocrinology 1992; 131:11071114.

45. Hardy MP, Zirkin BR, Ewing LL Kinetic studies on the development of the adult population of Leydig cells in testes of the pubertal rat. Endocrinology 1989; 124:762-770

46. Chemes HE. Leydig cell development in humans. In: Payne, AH, Hardy MP, Russell LD (Eds.), The Leydig
Cell. Cache River Press, 1996; Vienna, IL, pp. 175-201

47. Etchevers HC, Vincent C, Le Douarin NM, Couly GF. The cephalic neural crest provides pericytes and smooth muscle cells to all blood vessels of the face and forebrain. Development 2001; 128:1059-1068

48. Guillemin GJ, Brew BJ (2004) Microglia, macrophages perivascular macrophages, and pericytes: a review of function and identification. J Leukoc Biol 75: 388-397. DOI: $10.1189 /$ jlb.0303114

49. Trost A, Lange S, Schroedl F, Bruckner D, Motloch $\mathrm{KA}$, Bogner B, et al. Brain and retinal pericytes: origin, function and role. Front Cell Neurosci 2016; 10:20. DOI: $10.3389 /$ fncel.2016.00020

50. Sá-Pereira I, Brites D, Brito MA. Neurovascular unit: a focus on pericytes. Mol Neurobiol 2012; 45:327-347 DOI: $10.1007 / \mathrm{s} 12035-012-8244-2$

51. Rhodin JAG, Fujita H. Capillary growth in the mesentery of normal young rats. Intravital video and electron microscope analyses. J Submicrosc Cytol Pathol 1989; $21: 1-34$

52. Diaz-Flores L Jr, Madrid JF, Guitérrez R. Adult stem and transit-amplifying cell location. Histol Histopathol 2006; 21:995-1027. DOI: 10.14670/HH-21.995

53. Diaz-Flores L, Gutiérrez R, Madrid JF, Varela H, Valladares F, Acosta E, et al. Pericytes. Morphofunction, interactions and pathology in a quiescent and activated mesenchymal cell niche. Histol Histopathol 2009; 24: 909-969. DOI: 10.14670/HH-24.909

54. Mancini RF, Vilar O, Lavieri JC, Andrada JA, Heinrich JJ. Development of Leydig cells in the normal human testis: A cytological, cytochemical and quantitative study. Am J Anat 1963; 112: 203-214. DOI: 10.1002/ aja.1001120206

55. 54. Russell LD, de Franca LR. Building a testis. Tissue Cell 1995; 27: 129-147. DOI: 10.1016/S00408166(95)80016-6

56. Haider SG, Laue D, Schwochau G, Hilscher B. Morphological studies on the origin of adult-type Leydig cells in rat testis. Ital J Anat Embryol 1995; 100 (Suppl 1): $535-541$

57. Haider SG. Leydig cell steroidogenesis: unmasking the functional importance of mitochondria. Endocrinology 2007; 148: 2581-2582. DOI: 10.1210/en.2007-0330

58. Chemes HE. Leydig cell development in humans. In: Payne, AH, Hardy MP, Russell LD (Eds.), The Leydig Cell. Cache River Press, Vienna, IL, 1996; pp. 175-201

59. Kilcoyne KR, Smith LB, Atanassova N, Macpherson S, 
McKinell C, van den Driesche S, et al. Fetal programming of adult Leydig cell function by androgenic effects on stem/progenitor cells. Proc Natl Acad Sci USA 2014; 111: E1924-E1932. DOI: 10.1073/pnas.1320735111

60. Fecteau KA, Markonjich L, Mason JI, Mendis-Handagama SMLC. Detection of platelet-derived growth factor- $\alpha$ (PDGF-A) protein in cells of Leydig lineage in the postnatal rat testis. Histol Histopathol 2006; 21: 1295-1302. DOI: 10.14670/HH-21.1295.

61. Svingen T, Koopman P. Building the mammalian testis: origins, differentiation, and assembly of the component cell populations. Genes Dev 2013; 27: 2409-2426. DOI: $10.1101 / \mathrm{gad} .228080 .113$.

62. Kerr JB, Bartlett JMC, Donachie K, Sharpe RM. Origin of regenerating Leydig cells in the testis of adult rat. An ultrastructural, morphometric and hormonal study. Cell Tissue Res 1987; 249: 367-377. DOI: 10.1007/ BF00215521

63. Nehls V, Denzer K, Drenckhahn D. Pericyte involvement in capillary sprouting during angiogenesis in situ. Cell Tissue Res 1992; 270: 469-474. DOI: 10.1007/ BF00645048

64. Haider SG, Servos G. Ultracytochemistry of 3ß-hydroxysteroid dehydrogenase in Leydig cell precursors and vascular endothelial cells of the postnatal rat testis. Anat Embryol 1998: 198: 101-110. DOI: 10.1007/ s004290050168

65. Haider SG, Servos K, Tran N. Structural and histological analysis of Leydig cell steroidogenic function. In: Payne AH, Hardy MP (Eds), Contemporary Endocrinology: the Leydig Cell in Health and Disease. Humana Press Inc. Totowa, NJ, 2007; pp. 33-45

66. Ariyaratne HB, Mendis-Handagama SMLC. Changes in the testis interstitium of Sprague Dawley rats from birth to sexual maturity. Biol Reprod 2000; 62: 680690. DOI: 10.1095/biolreprod62.3.680

67. Allt G, Lawrenson JG Pericytes: cell biology and pathology. Cell Tiss Organs 2001; 169: 1-11. DOI: 10.1159/000047855

68. O'Shaughnessy PJ, Hu I, Baker PJ. Effect of germ cell depletion on levels of specific mRNA transcripts in mouse Sertoli cells and Leydig cells. Reproduction 2008; 135: 839-850. DOI: 10.1530/REP-08-0012

69. Stanley E, Lin C-Y, Jin S, Liu J, Sottas CM, Ge R et al. Identification, prtoliferation, and differentiation of adult Leydig stem cells. Endocrinology 2012; 153: 5002-5010. https://doi.org/10.1210/en.2012-1417
70. 69. Landreh L, Stukenborg J-B, Söder O, Svechnikov K Phenotype and steroidogenic potential of PDGF $\alpha$-positive rat neonatal peritubular cells. Mol Cell Endocrinol 2013; 372: 96-104. DOI: 10.1016/j. mce.2013.03.019

71. Landreh L, Spinner K, Schubert K, Häkkinen MR, Auriola $\mathrm{S}$, Poutanern $\mathrm{M}$, et al. Human testicular peritubular cells host putative stem Leydig cells with steroidogenic capacity. J Clin Endocrinol Metab 2014; DOI: 10.1210/jc.2013-4199

72. Danielian PS, Muccino D, Rowitch DH, Michael SK, McMahon AP. Modification of gene activity in mouse embryos in utero by a tamoxifen-inducible form of Cre-recombinase. Curr Biol 1998; 8: 1323-1326. DOI: 10.1016/s0960-9822(07)00562-3

73. Etchevers HC, Vincent C, Le Douarin NM, Couly GF. The cephalic neural crest provides pericytes and smooth muscle cells to all blood vessels of the face and forebrain. Development 2001; 128: 1059-1068.

74. Korn J, Christ B, Kurz H. Neuroectodermal origin of brain pericytes and vascular smooth muscle cells. J Comp Neurol 2002; 442: 78-88. DOI: 10.1002/ cne. 1423

75. Gage FH, Coates PW, Palmer TD, Kuhn HG, Fisher LJ, Suhonen JO, et al. Survival and differentiation of adult neuronal progenitor cells transplanted to the adult brain. Proc Natl Acad Sci USA 1995; 92:11879-11883

76. Müller SM, Stolt CC, Terswzowski G, Blum C, Amaqgai T, Kessaris N, Innarelli P, et al. Neural crest origin of perivascular mesenchyme in the adult thymus. J Immunol 2008; 180: 5344-5351.

77. Simon C, Lickert H, Götz M, Dimou L. Sox10-iCreERT2: a mouse line to inducibly trace the neural crest and oligodendrocyte lineage. Genesis 2011; 50: 506515. DOI: $10.1002 /$ dvg.22003

78. Trost A, Schroedl F, Lange S, Rivera FJ, Tempfer H, Korntner $\mathrm{S}$ et al. Neural crest origin of retinal and choroidal pericytes. Invest Ophthalmol Vis Sci 2013; 54: 7910-7921. DOI:10.1167/iovs.13-12946

79. Ergün S, Tilki D, Klein D.Vascular wall as a reservoir for different types of stem and progenitor cells. Antiox Redox Signal 2011; 15: 981-995. DOI: 10.1089/ ars.2010.3507

80. Corselli M, Chen C-W, Sun B, Yap S, Rubin JP, Péault B. The tunica adventitia of human arteries and veins as a source of mesenchymal stem cells. Stem Cells Dev 2012; 21: 1299-1308. DOI: 10.1089/scd.2011.0200 
81. Chen Q, Zhang H, Liu Y, Adams S, Eilken H, Stehling $\mathrm{M}$, et al. Endothelial cells are progenitors of cardiac pericytes and vascular smooth muscle cells. Nat Commun 2016; 7:12422. DOI: 10.1038/ncomms 12422

82. Ozerdem U, Alitalo K, Salven P, Andrew L. Contribution of bone marrow-derived pericyte precursor cells to corneal vasculogenesis. Invest Ophthalmol Vis Sci 2005; 46:3502-3506. DOI:10.1167/iovs.05-0309

83. Pfister F, Przybyt E, Harmsen MC, Hammes H-P. Pericytes in the eye. Pflüg Arch-Eur J Physiol 2013; 465: 789-796. DOI 10.1007/s00424-013-1272-6

84. Brennan J, Tilmann C, Capel B. PDGFR- $\alpha$ mediates testis cord organization and fetal Leydig cell development in the XY gonad. Genes Dev 2003; 17: 800-810. DOI:10.1101/gad.1052503

85. Jackson AE, O'Leary PC, Ayers MM, de Kretser DM. The effects of ethylene dimethane sulphonate (EDS) on rat Leydig cells: evidence to support a connective tissue origin of Leydig cells. Biol Reprod 1986; 35: 425437. DOI: 10.1095/biolreprod35.2.425

86. Jegou B , Pineau C. Current aspects of autocrine and paracrine regulation of spermatogenesis. In: Mukhopadhyay AK, Raizada MK (Eds), Tissue Renin-Angiotensin Systems. Current Concepts of Local Regulators in Reproductive and Endocrine Organs. Plenum Press, New York 1995; pp $67-86$

87. Shen Q, Goderie SK, Jin L, Karanth N, Sun Y, Abramova N, et al. Endothelial cells stimulate self-renewal and expand neurogenesis of neural stem cells. Science 2004; 304: 1338-1340. DOI: 10.1126/science.1095505

88. Ergün S, Stingl J, Holstein AF. Microvasculature of the human testis in correlation to Leydig cells and seminiferous tubules. Andrologia 1994; 26:255-62. DOI: 10.1111/j.1439-0272.1994.tb00799.x

89. Flamme I, Frölich T, Risau W. Molecular mechanisms of vasculogenesis and embryonic angiogenesis. J Cell Physiol 1997; 173: 206-210. DOI: 10.1002/(SICI)10974652(199711)173:2<206::AID-JCP22>3.0.CO;2-C

90. Nikolova G, Lammert E. Interdependent development of blood vessels and organs. Cell Tissue Res 2003; 314 : 33-42. DOI: 10.1007/s00441-003-0739-8

91. Chappell JC, Bautch VL.Vascular development: genetic mechanisms and links to vascular disease. Curr Top Dev Biol 2010; 90: 43-72. DOI 10.1016/S00702153(10)90002-1

92. Weerasooriya TR, Yamamoto T. Three-dimensional organization of the vasculature of the rat spermatic cord and testis. Cell Tissue Res 1985; 241: 317-323 DOI: 10.1007/BF00217176

93. Murakami T, Uno Y, Ohtsuka A, Taguchi T. The blood vascular architecture of the rat testis: a scanning electron microscopic study of corrosion casts followed by light microscopy of tissue sections. Arch Histol Cytol 1989; 52: 151-172. DOI: 10.1679/aohc.52.151

94. Suzuki F, Nagano T. Microvasculature of the human testis and excurrent duct system. Resin-casting and scanning electron-microscopic studies. Cell Tissue Res 1986; 243: 79-89. DOI: 10.1007/BF00221855

95. Javaherian A, Kriegstein A. A stem cell niche for intermediate progenitor cells of the embryonic cortex. Cerebral Cortex 2009; 19: i70-i77. DOI: 10.1093/cercor/ bhp029.

96. Palmer TD, Willhoite AR, Gage FH. Vascular niche for adult hippocampal neurogenesis. J Comp Neurol 2000; 425: 479-494. DOI: $10.1002 / 1096-9861(20001002) 425: 4<479::$ AIDCNE2>3.0.CO;2-3

97. Brennan J, Karl J, Capel B. Divergent vascular mechanisms downstream of Sry establish the arterial system in the XY gonad. Dev Biol 2002; 244: 418-428. DOI:10.1006/dbio.2002.0578

98. Combes AN, Wilhelm D, Davidson T, Dejana E, Harley $\mathrm{V}$, Sinclair A et al. Endothelial cell migration directs testis cord formation. Developmental Biology 2009; 326: 112-120 DOI:10.1016/j.ydbio.2008.10.040

99. Ergün S, Davidoff M, Holstein AF. Capillaries in the lamina propria of human seminiferous tubules are partly fenestrated. Cell Tissue Res 1996; 286: 93-102. DOI: $10.1007 / \mathrm{s} 004410050678$

100. Ergün S, Harneit S, Paust HJ, Mukhopadhyay AK, Holstein AF. Endothelin and endothelin receptors A and B in the human testis. Anat Embryol 1999; 199: 207-214.

101. da Silva Meirelles L, Caplan AI, Nardi NB. Pericytes as the source of mesenchymal stem cells. In: dos Santos Goldenberg RC, Campos de Carvalho AC (Eds) Resident Stem Cells and Regenerative Therapy 2013; pp. 233-250. Elsevier Inc. DOI:10.1016/B978-0-12416012-5.00012-8

102. Karow M. Mountaineering pericytes - A universal key to tissue repair? Bioassays 2013; 35: 771-774. DOI: 10.1002/bies.201300055

103. Joseph NM, Mukouyama YS, Mosher JT, Jaegle M, Crone SA, Dormand EL, et al. Neural crest stem cells undergo multilineage differentiation in developing pe- 
ripheral nerves to generate endoneural fibroblasts in addition to Schwann cells. Development 2004; 131: 55995612. DOI: 10.1242/dev.01429

104. Petrini M, Pacini S, Trombi L, Fazzi R, Montali M, Ikehara $\mathrm{S}$, et al. Identification and purification of mesodermal progenitor cells from human adult bone marrow. Stem Cells Dev 2009; 18: 857-866. DOI:10.1089/ scd.2008.029.

105. Pacini S, Carnicelli V, Trombi L, Montali M, Fazzi R, Lazzarini E, et al. Constitutive expression of pluripotency-associated genes in Mesodermal Progenitor Cells (MPCs). PLoS ONE 2010; 5:e9861. DOI: 10.1371/ journal.pone.0009861

106. Buehr M, Smith A. Genesis of embryonic stem cells. Phil Trans R Soc Lond B 2003; 358: 1397-1402. DOI: 10.1098/rstb.2003.1327

107. Rossant J. Stem cells from the mammalian blastocyst. Stem Cells 2001; 19: 477-482. DOI: 10.1634/stemcells.19-6-477

108. Smith, A. G. Embryo-derived stem cells: of mice and men. Ann Rev Cell Devl Biol 2001; 17: 435-462. DOI: 10.1146/annurev.cellbio.17.1.435

109. Li L, Xie T. Stem cell niche: Structure and function. Annu Rev Cell Dev Biol 2005; 21: 605-631. DOI: 10.1146/annurev.cellbio.21.012704.131525

110. ChenY-T, Chang F-C, Wu C-F, Chou Y-H, Hsu H-L, Chiang W-C, et al. Platelet-derived growth factor receptor signaling activates pericyte-myofibroblast transition in obstructive and post-ischemic kidney fibrosis. Kidney Intern 2011; 80: 1170-1181. DOI:10.1038/ ki.2011.208

111. Javaherian A, Kriegstein A. A stem cell niche for intermediate progenitor cells of the embryonic cortex. Cerebral Cortex 2009; 19: i70-i77. DOI: 10.1093/cercor/ bhp029.

112. Rompolas P, Mesa KR, Greco V. Spatial organization within a niche as a determinant of stem-cell fate. $\mathrm{Na}$ ture 2013; 502: 513-518. DOI:10.1038/nature12602

113. Iglesias-Bartolome R, Gutkind JS. Keeping the epidermal stem cell niche in shape. Cell Stem Cells 2010; 7: 143-145. DOI: 10.1016/j.stem.2010.07.008

114. Caplan AI. Mesenchymal stem cells. J Orthop Res 1991; 9: 641-650.

115. de Souza LEB, Malta TM, Kashima HS, Covas DT. Mesenchymal stem cells and pericytes: To what extent are they related? Stem Cells and Development. 2016; 25(24): 1843-1852. https://doi.org/10.1089/ scd.2016.0109

116. Lin C-S, Xin Z-C, Deng C-H, Ning H, Lin G, Lue T F. Defining adipose tissue-derived stem cells in tissue and in culture. Histol Histopathol 2010; 25: 807-815. DOI: 10.14670/HH-25.807.

117. Bouacida A, Rosset P, Trichet V, Guilloton F, Espagnolle $\mathrm{N}$, Cordonier T, et al. Pericyte-like progenitors show high immaturity and engraftment potential as compared with mesenchymal stem cells. PLoS ONE 2012; 7(11): e486548. DOI: 10.137/journal.pone.0048648

118. Mendes-Jorge L, Llombart C, Ramos D, López-Luppo $\mathrm{M}$, Valença A, Nacher V, et al. Intercapillary bridging cells: Immunocytochemical characteristics of cells that connect blood vessels in the retina. Exp Eye Res 2012; 98: 79-82. DOI:10.1016/j.exer.2012.03.010

119. Gökçinar-Yagei B, Uçkan-Çetinkaya, Çelebi-Saltik B. Pericytes: Properties, functions and applications in tissue engineering. Stem Cell Rev Rep 2015; 11: 549-559. DOI: $10.1007 / \mathrm{s} 12015-015-9590-\mathrm{z}$

120. Guimarães-Camboa N, Cattaneo P, Sun Y, Moore-Morris T, Gu Y, Dalton ND, et al. Pericytes of multiple organs do not behave as mesenchymal stem cells in vivo. Cell Stem Cell 2017; 20: 345-359. DOI.org/10.1016/j. stem.2016.12.006

121. Cano E, Gebala V, Gerhardt H. Pericytes or mesenchymal sdtem cells: Is that the question? Cell Stem Cell 2017; 20: 296-297. DOI: /10.1016/j.stem.2017.02.005

122. Lindner U, Kramer J, Rohwedel J, Schlenke P. Mesenchymal stem or stromal cells: Toward a better understanding of their biology? Transfus Med Hemother 2010; 37: 75-83. DOI: 10.1159/000290897

123. Zimmerlin L, Donnenberg VS, Pfeifer ME, Meyer EM, Péault B, Rubin JP, et al. Stromal vascular progenitors in adult human adipose tissue. Cytometry Part A 2010; 77A: 22-30. DOI: 10.1002/cyto.a.20813

124. Zimmerlin L, Donnenberg VS, Donnenberg AD, Pericytes: A universal adult tissue stem

125. Murray IR, West CC, Hardy WR, James AW, Park TS, Nguyen A et al. Natural history of mesenchymal stem cells, from vessel walls to culture vessels. Cell Mol Life Sci 2013; DOI 10.1007/s00018-013-1462-6

126. Dar A, Domev H, Ben-Yosef O, Tzukerman M, Zeevi-Levin N, Novak A, et al. Multipotent vasculogenic pericytes from human pluripotent stem cells pro mote recovery of murine ischemic limb. Circulation 2012; 125: 87-99. DOI: 10.1161/CIRCULATIONAHA. 111.048264 
127. Rowley JE, Johnson JR. Pericytes in chronic lung disease. Int Arch Allergy Immunol 2014; 164:178-188. DOI: $10.1159 / 000365051$

128. Tosh D, Slack JMW. How cells change their phenotype. Nature Rev 2002; 3: 187-194. DOI: 10.1038/nrm761

129. Shen CC, Kang Y-H, Yu L, Cui D-d, He Y, Yang J-L, Gou L-T. Human testis-expressed sequence 101 is limitedly distributed in germinal epithelium of testis and disappears in seminoma. Biol Res 2014; 47: 52. DOI:10.1186/0717-6287-47-52

130. Murasawa S, Kawamoto A, Horii M, Nakamori S, Asahara T. Niche-dependent translineage commitment of endothelial progenitor cells, not cell fusion in general, into myocardial lineage cells. Arterioscler Thromb Vasc Biol 2005; 25:1388-1394 DOI: 10.1161/01. ATV.0000168409.69960.e9

131. 130. Song L, Tuan RS. Transdifferentiation po ã q q tential of human mesenchymal stem cells derived from bone marrow. FASEB J 2004; 18: 980-982. DOI: 10.1096/fj.03-1100fje

132. Song L, Webb NE, Song Y, Tuan RS. Identification and functional analysis of candidate genes regulating mesenchymal stem cell self-renewal and multipotency. Stem Cells 2006; 24: 1707-1718. DOI: 10.1634/stemcells.2005-0604

133. Bianco P, Cossu G. Uno, nessuno e centomila: Searching for the identity of mesodermal progenitors. Exp Cell Res 1999; 251: 257-263. DOI: 10.1006/excr.1999.4592

134. De Angelis L, Berghella L, Coletta M, Lattanzi L, Zanchi M, Gabriella Cusella-De Angelis M, et al. Skeletal myogenic progenitors originating from embryonic dorsal aorta coexpress endothelial and myogenic markers and contribute to postnatal muscle growth and regeneration. J Cell Biol 1999; 147: 869-877. DOI: 10.1083/jcb.147.4.869

135. Minasi MG, Riminussi M, De Angelis L, Borello U, Berarducci $\mathrm{B}$, Innocenzi $\mathrm{A}$, et al. The meso-angioblast: a multipotent, self-renewing cell that originates from the dorsal aorta and differentiates into most mesodermal tissues. Development 2002; 129: 2773-2783.

136. Lin S-L, Kisseleva T, Brenner DA, Jeremy S. Duffield JS. Pericytes and perivascular fibroblasts are the primary source of collagen-producing cells in obstructive fibrosis of the kidney. Am J Pathol 2008; 173: 16171627. DOI: 10.2353/ajpath.2008.080433

137. Morrison SJ, Spradling AC. Stem cells and niches: mechanisms that promote stem cell maintenancxe throughout life. Cell 2008; 132: 598-611. DOI 10.1016/j.cell.2008.01.038

138. Rao M. Stem and precursor cells in the nervous system. J Neurotrauma 2004; 21(4): 415-427. DOI: 10.1089/089771504323004566

139. Tavian M, Zheng B, Oberlin E, Crisan M, Sun B, Huard $\mathrm{J}$, et al. The vascular wall as a source of stem cells. Ann NY Acad Sci 2005; 1044: 41-50. DOI: 10.1196/annals. 1349.006

140. Ge R-S, Dong Q, Sottas CM, Chen H, Zirkin BR, Hardy MP. Gene expression in rat Leydig cells during development from the progenitor to adult stage: a cluster analysis. Biol Reprod 2005; 72: 1405-1415. DOI: 10.1095/biolreprod.104.037499

141. Teerds K, Rijntjes E. Dynamics of Leydig cell regeneration after EDS. A model for postnatal Leydig cell development. In: Payne AH, Hardy MP (Eds), Contemporarry Endocrinology: The Leydig Cell in Health and Disease Humana Press Inc, Totowa, NJ, 2007; pp 91116

142. Lin C-S, Lue TF. Defining vascular stem cells. Stem Cells Dev 2013; 22: 1018-1026. DOI:10.1089/ scd.2012.0504

143. Petrakova KV, Kurolesova AI, Frolova GP. Heterotopic of bone marrow. Analysis of precursor cells for osteogenic and hematopoietic tissues. Transplantation 1968; 6, 230-247. DOI:10.1097/00007890-19680300000009

144. Friedenstein AJ, Chailakhyan RK, Latsinik NV, Panasyuk AF, Keiliss-Borok V. Stromal cells responsible for transferring the microenvironment of the hemopoietic tissues. Cloning in vitro and retransplantation in vivo. Transplantation 1974; 14: 331-340.

145. Horwitz EM, Le BK, Dominici M, Zetterberg E, Ringdén $\mathrm{O}$. Clarification of the nomenclature for MSC: the International Society for Cellular Therapy position statement. Cytotherapy 2005; 7: 393-395. DOI: 10.1080/14653240500319234

146. Dominici M, Le Blanc K, Mueller I, Slaper-Cortenbach I, Marini FC, Krause DS. Minimal criteria for defining multipotent mesenchymal stromal cells. The International Society for Cellular Therapy position statement. Cytotherapy 2006; 8:315-317. DOI: 10.1080/14653240600855905

147. Lamagna $\mathrm{C}$, Bergers $\mathrm{G}$. The bone marrow constitutes a reservoir of pericyte progenitors. J Leukoc Biol 2006; 80: 677-681. DOI: 10.1189/jlb.0506309 
148. Bexell D, Gunnarsson S, Tormin A, Darabi A, Gisselsson D, Roybon L. Bone marrow multipotent mesenchymal stroma cells act as pericyte-like migratory vehicles in experimental gliomas. Mol Ther 2009; 17: 183-190. DOI:10.1038/mt.2008.229

149. Nakagomi T, Kubo S, Nakano-Doi A, Sakuma R, Lu S, Narita A. Brain vascular pericytes following ischemia have multipotential stem cell activity to differentiate into neural and vascular lineage cells. Stem Cells 2015; 33: 1962-1974 DOI 10.1002/stem.1977

150. Zouani OF, Lei Y, Durrieu M-C. Pericytes, stem-celllike cells, but not mesenchymal stem cells are recruited to support microvascular tube stabilization. Small 2013; 9: 3070-3075. DOI: 10.1002/smll.201300124

151. Bianco P, Robey PG, Simmons PJ. Mesenchymal stem cells: revisiting history, concepts, and assays. Cell Stem Cells 2008; 2: 313-319. DOI: 10.1016/j. stem.2008.03.002.

152. Friedrich R, Holstein AF, Middendorff R, Davidoff MS. Vascular wall cells contribute to tumorigenesis in cutaneous neurofibromas of patients with neurofibromatosis type 1. A comparative histological, ultrastructural and immunohistochemical study. Anticancer Res 2012; 32: $2139-2158$

153. Göritz C, Dias DO, Tomilin N, Barbacid M, Shupliakov O, Frisén J. A pericyte origin of spinal cord scar tissue. Science 2011; 333: 238-242.

154. Tempel ZJ, Monaco EA III, Friedlander RM. Pericytes as a therapeutic target in scar formation after spinal cord injury. Science 2013; 73: N18-N20.

155. Kokovay E, Li L, Cunningham LA. Angiogenic recruitment of pericytes from bone marrow after stroke. J Cerebral Blood Flow Metabol 2006; 26: 545-555. DOI:10.1038/sj.jcbfm.9600214

156. Haider SG. Cell biology of Leydig cells in the testis. Int Rev Cytol 2004; 233: 181-241. DOI: 10.1016/S00747696(04)33005-6

157. Ariyaratne HB, Mendis-Handagama SMLC. Changes in the testis interstitium of Sprague Dawley rats from birth to sexual maturity. Biol Reprod 2000; 62: 680 690. https://doi.org/10.1095/biolreprod62.3.680

158. Shen Q, Wang W, Kokovay E, Lin G, Chang S-M, Goderie SK, et al. Adult ZVZ stem cells lie in a vascular niche: a quanitative analysis of niche-cell interactions. Cell Stem Cell 2008; 3: 289-300. DOI: 10.1016/j. stem.2008.07.025

159. Shen Q, Goderie SK, Jin L, Karanth N, Sun Y, Abram- ova N. Endothelial cells stimulate self-renewal and expand neurogenesis of neural stem cells. Science 2004; 304: 1338-1340. DOI: 10.1126/science. 1095505

160. McCarty JH. Cell biology of the neurovascular unit: implications for drug delivery across the blood-brain barrier. ASSAY Drug Dev Technol 2005; 3: 89-95. DOI:10.1089/adt.2005.3.89

161. McCarty JH. Cell adhesion and signaling networks in brain neurovascular units. Curr Opinion Hematol 2009; 16: 209-214.

162. Sá-Pereira I, Brites D, Brito MA. Neurovascular unit: a focus on pericytes. Mol Neurobiol 2012; 45: 327-347. DOI: $10.1007 / \mathrm{s} 12035-012-8244-2$

163. Itoh Y, Toriumi H, Yamada S, Hoshino H, Suzuki N. Astrocytes and pericytes cooperatively maintain a capillary-like structure composed of endothelial cells on gel matrix. Brain Res 2011; 1406: 74-83. DOI:10.1016/j. brainres.2011.06.039

164. Alvarez-Buylla A, Seri B, Doetsch F. Identification of neural stem cells in the adult vertebrate brain. Brain Res Bull 2002; 57: 751-758. DOI: 10.1016/S03619230(01)00770-5

165. Filippov V, Kronenberg G, Pivneva T, Reuter K, Steiner B, Wang L-P. Subpopulation of nestin-expressing progenitor cells in the adult murine hippocampus shows electrophysiological and morphological characteristics of astrocytes. Mol Cell Neurosci 2003; 23: 373-382. DOI:10.1016/S1044-7431(03)00060-5

166. Hill WD, Hess DC, Martin-Studdard A, Carotheres J J, Zheng J, Hale D, et al. SDF-1 (CXCL12) is upregulated in the ischemic penumbra following stroke: association with bone marrow cell homing to injury. $\mathrm{J} \mathrm{Neu}$ ropathol Exp Neurol 2004; 63: 84-96. DOI: 10.1093/ jnen/63.1.84

167. Sild M, Rithazer ES. Radial glía: progenitor, pathway, and partner. Neuroscience 2011; 17: 288-302. DOI: $10.1177 / 1073858410385870$

168. Gonzalez-Perez O. Neural stem cells in the adult human brain. Biol Biomed Rep 2012; 2(1) 59-69. DOI: $10.1155 / 2012 / 378356$

169. Jiang Y, Hernderson D, Blackstad M, Chen A, Miller RF, Verfaillie CM. Neuroectodermal differentiation from mouse multipotent adult progenitor cells. Proc Natl Acad Sci USA 2003; 100: 11854-11860. DOI: 10.1073/pnas.1834196100

170. Morshead CM. Adult neural stem cells: attempting to solve the identity crisis. Dev Neurosci 2004; 26: 93- 
199. DOI: $10.1159 / 000082130$

171. Wei LC, Shi M, Chen LW, Cao R, Zhang P, Chan YS. Nestin-containing cells express glial fibrillary acidic protein in the proliferative regions of central nervous system of postnatal developing and adult mice. Dev Brain Res 2002; 139: 9-17. PII: S0165-3806(02)005096

172. Zhu X, Bergles DE, Nishiyama A. NG2 cells generate both oligodendrogcytes and gray matter astrocytes. Development 2008; 135: 145-157. DOI:10.1242/ dev.004895

173. Hara Y, Nomura T, Yoshizaki K, Frisén J, Osumi N. Impaired hippocampal neurogenesis and vascular formation in ephrin-A5-deficient mice. Stem Cells 2010; 28:974-983. DOI: 10.1002/stem.427

174. Angelova P, Davidoff MS. Immunocytochemical demonstration of substance $\mathrm{P}$ in hamster Leydig cells during ontogenesis. Z Mikrosk Anat Forsch 1989; 103: 560 -566 .

175. Doetsch F. The glial identity of neural stem cells. Nat Neurosci 2003; 6: 1127-1134. DOI: 10.1038/nn1144

176. Angelova P, Davidoff MS, Baleva K, Staykova M. Substance $P$ and neuron-specific enolase-like immunoreactivity of rodent Leydig cells in tissue section and cell culture. Acta Histochem 1991: 91: 131-139. DOI: 10.1016/S0065-1281(11)80266-7

177. Chiwakata C, Brackmann B, Hunt N, Davidoff M, Schulze W, Ivell R. Tachykinin (Substance P) gene expression in Leydig cells of the human and mouse testis. Endocrinology 1991; 128: 2441-1448. DOI: 10.1210/ endo-128-5-2441

178. Davidoff MS, Middendorff R, Koeva Y, Pusch W, Jezek D , Muller D. Glial cell line-derived neurotrophic factor (GDNF) and its receptors GFR a-1 and GFR a-2 in the human testis. Ital J Anat Embryol 2001; 106 (Suppl 2): 173-180.

179. Middendorff R, Davidoff MS , Holstein AF. Neuroendocrine marker substances in human Leydig cells - changes by disturbances of testicular function. Andrologia 1993; 25: 257-262. DOI: 10.1111/j.14390272.1993.tb02722.x

180. Le Douarin NM, Dupin E. Multipotentiality of the neural crest. Curr Opin Genet Dev 2003; 13: 529-536. https://doi.org/10.1016/j.gde.2003.08.002

181. Barembaum M, Bronner-Fraser M. Early steps in neural crest specification. Seminars Cell Dev Biol 2005; 16: 642-646. DOI: 10.1016/j.semcdb.2005.06.006
182. Weston JA, Thiery JP. Pentimento: Neural crest and the origin of mesectoderm. Dev Biol 2015; 401: 37-61. DOI.org/10.1016/j.ydbio.2014.12.035

183. Weston J A, Yoshida H, Robinson V, Nishikawa S, Fraser ST, Nishikawa S. Neural crest and the origin of ectomesenchyme: neural fold heterogeneity suggests an alternative hypothesis. Dev Dyn 2004; 229: 118-130. DOI 10.1002/dvdy.10478

184. Breau MA, Pietri T, Stemmler MP, Thiery P, Weston JA. A nonneural epithelial domain of embryonic cranial neural folds gives rise to ectomesenchyme. Proc Natl Acad Sci USA 2008; 105: 7750-7755. DOI: 10.1073pnas.0711344105

185. Trainor PA, Melton KR, Manzanares M. Origins and plasticity of neural crest cells and their roles in jaw and craniofacial evolution. Int J Dev Biol 2003; 47: 541553

186. Trainor PA. Spezification and pattering of neural crest cells during craniofacial development. Brain Behav Evol 2005; 66: 266-280. DOI: 10.1159/000088130

187. Crane JF, Trainor PA. Neural crest stem and progenitor cells. Ann Rev Dev Biol 2006; 22: 267-286. DOI: 10.1146/annurev.cellbio.22.010305.103814

188. 187. Kojima Y, Kaufman-Francis K, Studdert JB, Steiner KA, Power MD, Loebel DAF et al.. The transcriptional and functional properties of mouse epiblast stem cells resemble the anterior primitive streak. Cell Stem Cell 2014;14:107-120. DOI: 10.1016/j.stem.2013.09.014

189. Griswold SL, Behringer RR. Fetal Leydig cell origin and development. Sex Dev 2009; 3:1-15. DOI: $10.1159 / 000200077$

190. Tam PP, Loebel DA. Gene function in mouse embryogenesis: get set for gastrulation. Nat Rev Genet 2007; 8: 368-381. DOI: 10.1038/nrg2084

191. Pauklin S, Pedersen RA, Vallier L. Mouse pluripotent stem cells at a glance. J Cell Sci 2011; 124: 3727-3732. DOI:10.1242/jcs.074120

192. Lee RTH, Negai H, Nakaya Y, Sheng G, Trainor PA, Weston JA. Cell delamination in the mesencephalic neural fold and its implication for the origin of ectomesenchyme. Development 2013; 140: 4890-4902. DOI:10.1242/dev.094680

193. Donoghue PCJ, Graham A, Kelsh RN. The origin and evolution of the neural crest. Bioessays 2008; 30: 530541. DOI:10.1002/bies.20767.

194. Nichols DH. Formation and distribution of neural crest mesenchyme to the first pharyngeal arch region of the 
mouse embryo. Am J Anat 1986; 176:221-231.

195. Nichols DH. Neural crest formation in the head of the mouse embryo as observed using a new histological technique. J Embryol Exp Morph 1981; 64:105-120.

196. Spence SG, Poole TJ. Developing blood vessels and associated extracellular matrix as substrates for neural crest migration in Japanese quail, Coturnix coturnix japonica. Int J Dev Biol 1994; 38: 85-98.

197. Maekawa M, Kamimura K, Nagano T. Peritubular myoid cells in the testis: their structure and function. Arch Histol Cytol 1996; 59: 1-13

198. Ge R-S, Dong Q, Sottas CM, Papadopoulos V, Zirkin BR, Hardy MP. In search of rat stem Leydig cells: identification, isolation, and lineage-specific development. Proc Natl Acad Sci USA 2006; 103: 2719-2724. DOI: 10.1073/pnas.0507692103

199. Hall AP. Review of the pericyte during angiogenesis and its role in cancer and diabetic retinopathy. Toxicol Pathol 2006; 34: 763-775. DOI: 10.1080/01926230600936290

200. Diaz-Flores L, Gutiérrez R, Garcia MP, Diaz-Flores L Jr, Valladares F, Madrid JF. Ultrastructure of myopericytoma: a continuum of transitional phenotypes of myopericytes. Ultrastr Pathol 2012; 36: 189-194. DOI: 10.3109/01913123.2012.655855

201. Ribatti D, Vacca A. Overview of angiogenesis during tumor growth. In: Figg WD, Folkman J (Eds), Angiogenesis. An Integrative Approach from Science to Medicine, Springer 2008; pp 161-167.

202. Hosaka K, Yang Y, Sekia T, Fischera C, Dubeya O, Fredlundc E, et al. Pericyte-fibroblast transition promotes tumor growth and metastasis. Proc Natl Acad Sci USA 2016; 113(36): E5618-E5627. DOI: 10.1073/ pnas. 1608384113

203. Rowley JE, Johnson JR. Pericytes in chronic lung disease. Int Arch Allergy Immunol 2014; 164:178-188. DOI: 10.1159/000365051

204. Basciani S, Mariani S, Arizzi M , Ulisse S, Rucci N, Jannini EA, et al. Expression of platelet-derived growth factor-A (PDGF-A), PDGF-B, and PDGF receptor-a and -s during human testicular development and disease. J Clin Endocrinol Metab 2002; 87: 2310-2319. DOI: $10.1210 /$ jcem.87.5.8476

205. Gnessi L, Emidi A, Jannini EA, Carosa E, Maroder M, Arizzi M, et al. Testicular development involves the spatiotemporal control of PDGFs and PDGF receptors gene expression and action. J Cell Biol 1995; 131: 1105-1121.
206. Gnessi L, Basciani S, Mariani S, Arizzi M, Spera G, Wang $\mathrm{C}$, et al. Leydig cell loss and spermatogenic arrest in platelet-derived growth factor (PDGF)-A-deficient mice. J Cell Biol 2000; 149: 1019-1025.

207. Mariani S, Basciani S, Arizzi M, Spera G, Gnessi L. PDGF and the testis. Trends Endocrinol Metab 2002; 13: 11-17. DOI: 10.1016/S1043-2760(01)00518-5

208. Shan L-X, Zhu L-J, Bardin CW, Hardy MP. Quantitative analysis of androgen receptor messenger ribonucleic acid in developing Leydig cells and Sertolli cells by in situ hybridiszation. Endocrinology 1995; 136: 3856- 3862. DOI: 10.1210/endo.136.9.7649092

209. Welsh M, Saunders PT, Atanassova N, Sharpe R, Smith LB. Androgen action via testicular peritubular myoid cells is essential for male fertility. FASEB J 2009; 23: 4218-4230. DOI: 10.1096/fj.09-138347

210. Welsh M, Sharpe RM, Moffat L, Atanassova N, Saunders PTK, Kilter S, et al. Androgen action via testicular arteriole smooth muscle cells is important for Leydig cell function, vasomotion and testicular fluid dynamics. PLoS ONE 2010; 5(10): e13632. DOI:10.1371/ journal.pone.0013632

211. Welsh M, Moffat L, Belling K, de França LR, Segatelli TM, Saunders PTK et al. Androgen receptor signaling in peritubular myoid cells is essential for normal differentiation and function of adult Leydig cells. Int $J$ Androl 2011; 35: 25-40. DOI:10.1111/j.13652605.2011.01150.x

212. Bergh A, Amber JED. Immunohistochemical demonstration of androgen receptors on testicular blood vessels. Int J Androl 1992; 15: 425-434. DOI: 10.1111/ j.1365-2605.1992.tb01357.x

213. Huang C-K, Tsai M-Y, Luo J, Kang H-Y, Lee SO, Chang C. Suppression of androgen receptor enhances the selfrenewal of mesenchymal stem cells through elevated expression of EGFR. Biochim Biophy Acta 2013; 1833: 1222-1234. DOI: 10.1016/j.bbamcr.2013.01.007

214. Shan L-X, Bardin CW, Hardy MP. Immunohistochemical analysis of androgen effects on androgen receptor expression in developing Leydig and Sertoli cells. Endocrinology 1997; 138: 1259-1266. DOI:10.1210/ endo.138.3.4973

215. Takamoto N, You L-R, Moses K, Chiang C, Zimmer WE, Schwartz RJ, et al. COUP-TFII is essential for radial and anteroposterior pattering of the stomach. Development 2005; 132: 2179- 2189. DOI: 10.1242/ dev.01808 
216. Shibata H, Ikeda Y, Mukai T, Morohashi K-i, Kurihara I, Ando T, et al. Expression profiles of COUP-TF, DAX-1, and SF-1 in human adrenal gland and adrenocortical tumors: possible implications in steroidogenesis. Mol Gen Metab 2001; 74: 206-216. DOI: 10.1006/ mgme.2001.3231

217. Bischofberger J, Schmidt-Hieber C. Adulte Neurogenese im Hippocampus. Neuroforum 2006; 3: 212-221.

218. Dardick I, Poznanski WJ, Waheed I, Setterfield G. U1trastructural observations on differentiating human preadipocytes cultured in vitro. Tissue Cell 1976; 8: 561-571.

219. Rolandsson S, Sjöland AA, Brune JC, Li H, Kassem M, Mertens F, et al. Primary mesenchymal stem cells in human transplanted lungs are CD90/CD105 perivascularly located tissue-resident cells. BMJ Open Resp Res 2014; 1:e000027. DOI:10.1136/bmjresp-2014- 000027

220. Yang J, Weinberg RA. Epithelial-mesenchymal transition: At the crossroads of development and tumor metastasis. Dev Cell 2008; 14: 818-829.
221. Kalluri R, Weinberg RA. The basics of epithelial-mesenchymal transition. J Clin Invest 2009; 119: 14201428.

222. Lamouille S, Xu J, Derynck R. Molecular mechanisms of epithelial-mesenchymal transition. Nat Rev Mol Cell Biol 2014; 15: 178-196. DOI: 10.1038/nrm3758

223. Tavazoie M, Van der Veke L, Silva-VargaV, Louissaint M, Colonna L, Zaidi B, et al. A specialized vascular niche for adult neural stem cells. Cell Stem Cell 2008; 3: 279-288. DOI: 10.1016/j.stem.2008.07.025

224. Yao HH-C, Barsoum I. Fetal Leydig cells. Origin, regulation, and function. In: Payne AH, Hardy MP (Eds), Contemporary Endocrinology: The Leydig Cell in Health and Disease. Humana Press, Totowa, 2007; pp. 47-54.

225. Kennedy E, Mooney CJ, Hakimjavadi R, Fitzpatrick E, Guha S, Collins LE, et al. Adult vascular smooth muscle cells in culture express neural stem cell markers typical of resident multipotent vascular stem cells. Cell Tissue Res 2014; 358: 203-216. DOI 10.1007/s00441014-1937-2 